\title{
A STUDY OF THE RESIDUAL EFFECTS OF PHOSGENE POISONING IN HUMAN SUBJECTS. I. AFTER ACUTE EXPOSURE
}

\author{
BY MORTON GALDSTON, ${ }^{1}$ JOHN A. LUETSCHER, JR., WARFIELD T. LONGCOPE, \\ AND NICHOLAS L. BALLICH, WITH THE ASSISTANCE OF VIRGINIA L. \\ KREMER, GILES L. FILLEY, AND JOHN L. HOPSON \\ (From the Clinical Research Section, Medical Division, Chemical Warfare Service, Edgewood \\ Arsenal, Maryland, and The Department of Medicine, Johns Hopkins \\ Hospital, Baltimore, Maryland ${ }^{2}$ )
}

(Received for publication March 4, 1946)

\section{INTRODUCTION}

During World War I the British Chemical Warfare Medical Committee (1 to 8 ) recognized a distinctive syndrome which resulted most often from exposure to phosgene and which resembled in symptomatology the "Irritable Heart" or "Effort Syndrome." The patients presented scant physical evidence of structural disease of the lungs. Haldane and his co-workers emphasized that these symptoms were associated with rapid, shallow breathing (3). Although no measurements of the oxygen of the blood were reported, the cyanosis, polycythemia, and relief after inhalation of oxygen suggested that anoxemia was an important factor $(2,6)$. Furthermore, it was suggested that rapid, shallow breathing alone might produce anoxemia (5). Haldane, Meakins, and Priestley (5) state that "as soon as the exaggerated Hering-Breuer reflex has been produced by gassing or any other cause, the resulting slight anoxemia produces a general nervous upset in which various reflexes tend to be abnormal or exaggerated. The exaggeration of the HeringBreuer reflex itself may thus be kept up and with it the anoxemia." The patients were treated with oxygen inhalation. They were encouraged to take gradually increasing exercise. The majority of patients improved, but a considerable number were unable to return to duty ( 1 to 8 ).

The British Ministry of Pensions maintained that serious structural after-effects did not occur, provided the lungs were healthy before gassing. Only a few casualties suffered from chronic bronchitic attacks $(9,10)$. On the other hand, numer-

1 Captain, MC, A.U.S.

2 Study carried out at the Johns Hopkins Hospital, Baltimore, Maryland, under a contract with the OEMcmr and a Medical Division, OC, CWS, Work Project Specification. ous reports in the French and American literature have presented clinical evidence of residual damage to the lungs among phosgene and other types of chemical warfare casualties in the form of one or more of the following : chronic bronchitis, pulmonary emphysema, obliterative bronchiolitis, peribronchiolitis, bronchiectasis and suppuration of the lungs (11 to 18 ).

In spite of these valuable observations, there are too few objective measurements to indicate whether such patients have structural damage to the lungs, or simply a reflex or psychological disturbance. With the development of more precise methods for the evaluation of the ventilation of the lungs and the aeration of the blood, it is possible to study in greater detail these aspects in patients after exposure to phosgene. The cardiovascular system and the patients' psychological reactions also warrant more detailed study.

\section{EXPERIMENTAL}

Six patients, who are known to have been exposed to phosgene and who developed symptoms of acute poisoning, volunteered for the studies here reported.

\section{METHODS}

1. PULMONARY FUnCtion tests. These consisted of ventilatory function tests which are concerned with movement of air into and out of the lungs and respiratory function tests which are concerned with exchange of oxygen and carbon dioxide in the lungs.

\section{A. Ventilatory function tests.}

a. Lung volume measurements. Vital capacity, complementary air, tidal air, and reserve air were measured from graphic tracings of a spirometer. All volumes are expressed as gas saturated with water vapor at $37^{\circ} \mathrm{C}$. and prevailing barometric pressure.

b. Mid-capacity (functional residual air). This was measured by the method of Darling, Cournand, and 
Richards (19). The mid-capacity minus the reserve air represents residual air. ${ }^{3}$

c. Respiratory dead space. This was calculated according to Bohr's formula (23). It included an instrumental dead space of $100 \mathrm{ml}$.

d. Intrapulmonary mixing of gases. This was studied by the method of Darling, Cournand, and Richards (24). The presentation of the mixing curves has been changed by reversing the axes of the semi-logarithmic scale. This changes the sigmoid curve used by Darling and his coworkers (24) to a much simpler form consisting chiefly of two straight lines, the falling line of nitrogen dilution and the final level reached when the only remaining nitrogen is that eliminated from the blood. This curve is easier to construct, only two points being needed to define its form. It has the additional advantage that all deviations from the predicted values are represented in proportion to their significance, regardless of the level of alveolar nitrogen.

e. Completeness of emptying of lung nitrogen. This was measured as described by Cournand et al. (20).

f. Rate and depth of respiration. These were measured in a recording spirometer at rest, during exercise, and on recovery from exercise.

g. Voluntary breathing capacity (maximum breathing capacity). This was measured according to Cournand and Richards (25). These investigators kindly sent us the formulae for prediction of maximum breathing capacity.

h. Breath-holding. This was performed in moderate inspiration. At the end, a sample of alveolar air was collected and analyzed for oxygen and carbon dioxide content. Observations were also made on the effect of hyperventilation, for one minute, and oxygen breathing for two or three minutes, singly or combined on the duration of breath-holding. A breath-holding time of less than 25-30 seconds when breathing room air was considered limited.

\section{B. Respiratory function tests.}

a. Oxygen content and capacity of arterial blood. These were each measured in $1 \mathrm{mil}$. of blood (26).

b. Tension of oxygen and carbon dioxide in arterial blood. These were measured according to the method of

\footnotetext{
3 The published data on the per cent of the total lung volume comprised of residual air in normal individuals show 2 wide range of variation $(20,21,22)$. Moreover there has been some variation in results with the same method in different laboratories $(21,22)$ (Figure 1). This may be due to the fact that the number of individuals studied in each age group has not been comparable. Furthermore, differences in method may lead to some divergence of results, particularly in instances of pulmonary disease (20). There are enough data with each method to reach a general idea of the mean and range, but not enough to be completely satisfactory. It is necessary, therefore, to withhold final judgment on borderline abnormalities until more data can be obtained on normal individuals of comparable age with the same technique as used on the patients in this study (Figure 1).
}

Riley (27). In most instances duplicate samples of blood were drawn a few minutes apart. The post exercise arterial blood samples were usually obtained at $1 / 2$ to 1 minute and 3 to 5 minutes after exercise. Alveolar air was collected at the end of withdrawal of blood. At rest, the air was collected at the end of expiration; after exercise, at the height of inspiration. The range of oxygen tension values of arterial blood for each observation listed in the tables is in most instances based on three analyses, occasionally on two, four or five.4

c. $\mathrm{pH}$, carbon dioxide content, and tension of plasma. Arterial blood was drawn anaerobically into a syringe wet with heparin. The $\mathrm{pH}$ determination was made at room temperature with a sealed glass electrode which was standardized empirically with plasma equilibrated at $37^{\circ}$ C. with gas of known partial pressure of carbon dioxide. The carbon dioxide content of the plasma was measured (26) and its carbon dioxide tension was calculated from Peters' chart (31).

d. The oxygen extraction and carbon dioxide output per volume of air breathed at rest, during exercise and recovery. These were measured on expired air collected in a spirometer. At various times, a bicycle ergometer, a flight of steps, and single step (25) were used depending upon the degree of exercise desired. In the oxygen tension studies; exercise was continued for 30 seconds beyond the time the patient experienced marked shortness of breath. The rate, depth, and minute volume of respiration was recorded at the start of the exercise and during the last 30 seconds. Expired air was collected until the alveolar air sample was taken. The range of normal values for the step test (25) based on unpublished data was kindly sent to us by Drs. Cournand and Richards.

2. Circulatory Function studies.

a. Postural tests. The patient lay on a tilt table while observations of pulse and arterial blood pressure and recordings of rate and depth of breathing were made. When a steady base line had been established the patient was shifted from the horizontal to the $90^{\circ}$ vertical position. When the circulation and breathing reached a constant level, the patient was returned to the horizontal position where similar observations were made.

b. Ballistocardiographic studies of cardiac output. These were performed by Dr. Giles F. Filley on an instrument designed by Dr. Dugald S. Brown (32) and calibrated to correspond with Starr's instrument. Calculations were based on the area formula (33).

4 In 21 comparisons performed in 17 healthy resting subjects, the alveolar air $\mathrm{pO}_{2}$ range was 89 to $103 \mathrm{~mm}$. $\mathrm{Hg}$, average $99 \mathrm{~mm} . \mathrm{Hg}$ and the arterial blood $\mathrm{pO}_{2}$ range was 87 to $101 \mathrm{~mm} . \mathrm{Hg}$, average $98 \mathrm{~mm}$. $\mathrm{Hg}$. These agree essentially with similar studies recently reported $(28,29)$. In 11 comparisons in 9 healthy subjects, post exercise, the alveolar air $\mathrm{pO}_{2}$ range was 98 to $118 \mathrm{~mm}$. $\mathrm{Hg}$, average $115 \mathrm{~mm} . \mathrm{Hg}$ and the arterial blood $\mathrm{pO}_{2}$ range was 92 to $114 \mathrm{~mm}$. $\mathrm{Hg}$, average $110 \mathrm{~mm}$. $\mathrm{Hg}$. The post-exercise studies were carried out in subjects who had volunteered for the studies at rest (30). 
3. PSYCHIATRIC EXAMINATIONS.

These were performed in all 6 patients and in patients $2,3,4,5$, of the chronically exposed group (34) by Dr. Nicholas L. Ballich. The psychiatric summaries are presented in the Appendix.

4. OTHER STUDIES.

In all patients roentgenograms of the chest and electrocardiograms were taken. Blood counts, blood chemical studies, urine examinations, and other studies were performed as indicated.

\section{RESULTS}

The results are presented in detail in the Appendix and are summarized in Table I.

TABLE I

Summary of clinical observations and data on studies performed

\begin{tabular}{|c|c|c|c|c|c|c|}
\hline Case Number* & 1 & 2 & 3 & 4 & 5 & 6 \\
\hline 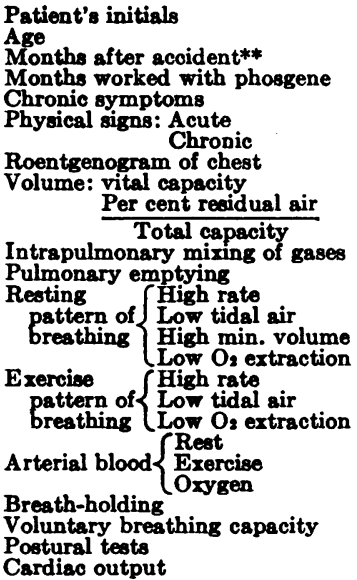 & $\begin{array}{c}\mathbf{E} . \mathbf{T} \\
\mathbf{3 8} \\
\mathbf{1 4} \\
\mathbf{6} \\
\mathbf{A} \\
\mathbf{A} \\
\mathbf{N} \\
\mathbf{N} \\
\mathbf{N} \\
\mathbf{B} \\
\mathbf{N} \\
\mathbf{N} \\
\mathbf{N} \\
\mathbf{N} \\
\mathbf{N} \\
\mathbf{B} \\
\mathbf{N} \\
\mathbf{B} \\
\mathbf{N} \\
\mathbf{N} \\
\mathbf{N} \\
\mathbf{N} \\
\mathbf{N} \\
\mathbf{N} \\
\mathbf{N}\end{array}$ & $\begin{array}{l}\mathbf{L} \mathbf{W} \\
\mathbf{3 9} \\
\mathbf{6} \\
\mathbf{1 2} \\
\mathbf{N} \\
\mathbf{A} \\
\mathbf{N} \\
\mathbf{N} \\
\mathbf{N} \\
\mathbf{N} \\
\mathbf{N} \\
\mathbf{N} \\
\mathbf{A} \\
\mathbf{N} \\
\mathbf{A} \\
\mathbf{A} \\
\mathbf{B} \\
\mathbf{N} \\
\mathbf{N} \\
\mathbf{A} \\
\mathbf{A} \\
\mathbf{N} \\
\mathbf{N} \\
\mathbf{A} \\
\mathbf{N} \\
\mathbf{A}\end{array}$ & $\begin{array}{c}\mathbf{H} . \mathbf{G} . \\
\mathbf{3 0} \\
\mathbf{6} \\
\mathbf{1 8} \\
\mathbf{N} \\
\mathbf{A} \\
\mathbf{N} \\
\mathbf{N} \\
\mathbf{N} \\
\mathbf{N} \\
\mathbf{B} \\
\mathbf{N} \\
\mathbf{A} \\
\mathbf{A} \\
\mathbf{A} \\
\mathbf{A} \\
\mathbf{B} \\
\mathbf{B} \\
\mathbf{N} \\
\mathbf{N} \\
\mathbf{N} \\
\mathbf{N} \\
\mathbf{A} \\
\mathbf{N} \\
\mathbf{N}\end{array}$ & $\begin{array}{c}\mathbf{L} . \mathbf{T} . \\
\mathbf{4 8} \\
\mathbf{3} \\
\mathbf{2} \\
\mathbf{A} \\
\mathbf{A} \\
\mathbf{B} \\
\mathbf{N} \\
\mathbf{A} \\
\mathbf{B} \\
\mathbf{A} \\
\mathbf{A} \\
\mathbf{A} \\
\mathbf{B} \\
\mathbf{A} \\
\mathbf{B} \\
\mathbf{B} \\
\mathbf{B} \\
\mathbf{B} \\
\mathbf{N} \\
\mathbf{N} \\
\mathbf{N} \\
\mathbf{A} \\
\mathbf{N} \\
\mathbf{N} \\
\mathbf{N}\end{array}$ & $\begin{array}{r}\mathbf{8 . 0} . \\
\mathbf{4 3} \\
\mathbf{5} \\
\mathbf{2} \\
\mathbf{A} \\
\mathbf{N} \\
\mathbf{N} \\
\mathbf{N} \\
\mathbf{N} \\
\mathbf{N} \\
\mathbf{N} \\
\mathbf{N} \\
\mathbf{A} \\
\mathbf{A} \\
\mathbf{A} \\
\mathbf{A} \\
\mathbf{A} \\
\mathbf{N} \\
\mathbf{A} \\
\mathbf{A} \\
\mathbf{N} \\
\mathbf{A} \\
\mathbf{A} \\
\mathbf{A} \\
\mathbf{N} \\
\mathbf{Z}\end{array}$ & $\begin{array}{c}\mathbf{M . P} \\
\mathbf{4 9} \\
\mathbf{5} \\
\mathbf{1} \\
\mathbf{A} \\
\mathbf{N} \\
\mathbf{N} \\
\mathbf{N} \\
\mathbf{N} \\
\mathbf{N} \\
\mathbf{B} \\
\mathbf{B} \\
\mathbf{A} \\
\mathbf{A} \\
\mathbf{A} \\
\mathbf{A} \\
\mathbf{A} \\
\mathbf{A} \\
\mathbf{A} \\
\mathbf{N} \\
\mathbf{N} \\
\overrightarrow{\mathbf{N}} \\
\mathbf{N} \\
\mathbf{N} \\
\mathbf{N}\end{array}$ \\
\hline
\end{tabular}

A = Definitely abnormal.

$\mathbf{N}=$ Normal.

B $=$ Borderline abnormal.

* Listed in order of severity of exposure.

** Applies to all special studies except arterial blood and alveolar air oxygen and carbon dioxide tensions and cardiac output which were performed 4 to 8 months later. Symptoms, physical and roentgenographic findings were unchanged on re-examination of all available patients (All except 5) 4 to 8 months later.

\section{DISCUSSION}

This small group of patients presents symptoms very similar to those observed after phosgene poisoning in World War I ( 1 to 8 ). These symptoms are similar from patient to patient, but some individuals appear to suffer much more than others. The patients complained regularly of shortness of breath, tightness of the chest, and precordial pain at rest or after slight exertion.
Cough was disturbing, particularly on exertion and at night, but only a little mucoid sputum was produced. Sleep was often disturbed by anxiety, terrifying dreams, dyspnea, and cough. Nausea, vomiting, and diarrhea were occasionally present. Several patients complained of nervousness and fatigue.

The most impressive feature of the physical examination was the rapid, generally shallow breathing, previously described by Haldane $e t$ al. (5). This pattern of respiration was present during sleep. Breathing was regular and not interrupted by sighs, which have been observed in respiratory neuroses $(35,36,37)$. The patients with complaints looked anxious. The hands were often cold and clammy. Otherwise, the physical examination presented no significant abnormality.

There was no tendency to polycythemia such as was observed during World War I (2). The red blood cell count, hemoglobin, and hematocrit were within the normal range or slightly below normal. Arterial and venous pressures were normal. Roentgenograms of the chest did not exhibit any abnormality of the lungs or heart, except for a healed tuberculous focus in two patients.

The studies of pulmonary function revealed a number of borderline changes and frank abnormalities in lung volume, intrapulmonary mixing of gases, and transfer of oxygen to the arterial blood. Some abnormality was observed in every patient, but there was no consistent pattern and the severity of the changes could not be correlated with the patients' symptoms.

The most striking and consistent abnormalities brought out by these studies were concerned with the rapid and usually shallow pattern of respiration. This pattern was present both at rest and during exercise and was accompanied by a low extraction of oxygen and a low output of carbon dioxide per unit of air breathed. These abnormalities are closely related and have been described after phosgene poisoning $(3,5)$. In contrast to Haldane's findings ( 3 ), however, the unusual pattern of respiration was not altered by breathing pure oxygen, and could be voluntarily slowed and deepened to a normal level. The limitation of breath-holding to a few seconds, described by Haldane et al. (5), was not observed in our patients, who could generally hold a breath for a 
normal time and who responded to hyperventilation or breathing oxygen with a prolongation of breath-holding time. Voluntary breathing capacity was significantly reduced in three of the six patients (cases $2,3,5$ ). It is of interest that these three patients had a normal vital capacity.

The alveolar air oxygen tension was normal or high in this group of patients. Haldane and his co-workers (3) made a similar observation and remarked upon the paradox of a normal alveolar air and apparent anoxemia without obvious anatomical disease of the lungs. They postulated unequal ventilation during shallow breathing in which certain alveoli were poorly ventilated and contributed little to the alveolar air specimen, which came primarily from well-ventilated alveoli. This inefficient pulmonary ventilation resulted in anoxemia. Certain indirect evidence was brought forward to support this view (38). Some observations on our patients do not substantiate certain of Haldane's postulates.

Anoxemia was present in only one of the six patients (case 5). In this patient, intrapulmonary mixing of gases was normal as measured by the nitrogen dilution method. In one other patient (case 2) who did not exhibit anoxemia, a disturbance in the transfer of oxygen to arterial blood existed without demonstrably impaired intrapulmonary mixing of gases. It is therefore apparent that in our group of patients, anoxemia is infrequent and is not necessarily dependent on impaired mixing of gases in the lung. A wellmarked defect of intrapulmonary mixing of gases was' not associated with anoxemia, even with shallow breathing, in three patients chronically exposed to phosgene (34).

Electroencephalograms and conditioned reflex studies, designed to detect possible diffuse cortical damage resulting from anoxemia, showed minimal changes in the acute stage and essentially normal patterns when repeated several weeks later. On the basis of these tests, it was not possible to demonstrate any clear-cut, irreversible, organic involvement of the cerebral cortex.

Although the nitrogen-dilution method does not show a consistent abnormality of intrapulmonary mixing of gases during shallow breathing, a tendency toward impaired mixing during shallow breathing is apparent when all observations on patients exposed to phosgene are charted (Figure 2).

Exercise to the point of dyspnea, then maintained for a half minute, did not produce anoxemia in any patient and actually abolished the anoxemia in one patient (case 5 ).

Postural tests indicated that there was no instability of vascular control nor any accompanying respiratory change. The ballistocardiographic tracings indicated a subnormal cardiac output in one patient (case 2). No case showed the changes described by Starr in a large proportion of his cases of neurocirculatory asthenia (39).

The results of these studies demonstrate certain disturbances of pulmonary function which were not recognized on clinical examination. The changes were probably not serious enough to account for the disabling symptoms present in some of the patients. There was no obvious change in symptoms, physical findings, or roentgenograms for as long as a,year and a half after exposure, but a detailed reexamination of the patients after a number of years would be necessary to decide whether the disease would recede or progress.

The correlation of the psychiatric abnormalities with the severity of symptoms was quite obvious. The timid and apprehensive patients developed disabling hypochondriacal and anxiety reactions. Pre-existing maladjustments and insecurity helped to perpetuate the symptoms. Socio-economic factors and previous personality trends were outstandingly important. Visible emotional support in the form of substantial personal contacts tended to stabilize the patient's reactions. Hospitalization and sympathy resulted in minimal improvement of symptoms and an increasing tendency toward chronic invalidism. Although compensation was rarely mentioned, the potential financial and psychological gains of invalidism loomed large to the insecure patients.

Three important points may be drawn from these data. Definite abnormalitiés in pulmonary function may persist for at least a year after exposure to phosgene. A characteristic change in the pattern of breathing accompanies these changes in the lungs. Symptoms, are quite uniform in type, but the severity of symptoms and the ensuing disability are much more closely related to the patient's psychological reactions than to any demonstrable physical or physiological abnormality. 
The disturbances in pulmonary function are almost certainly a reflection of organic changes in the lungs as a result of exposure to phosgene. The disturbances are generally suggestive of damage to the bronchioles and surrounding parenchyma as seen in beginning pulmonary emphysema.

The rapid, shallow breathing is probably also a consequence of pulmonary injury. This is perhaps due to a disturbance in the nerve-endings concerned with the stretch reflex of the lungs (Hering-Breuer). The same pattern of breathing occurs in men chronically exposed to phosgene (34). The persistence of this pattern of breathing during sleep and its occurrence in patients without complaints point strongly to a physiologic rather than a neurotic basis. Furthermore, the graphic respiratory records of our patients after recovery from phosgene poisoning show none of the features of a respiratory neurosis $(35,36,37)$. The results of our studies also indicate that anoxemia is not necessarily a consequence of shallow breathing and is not an essential factor for its persistence as suggested by $\mathrm{Hal}-$ dane and his co-workers (5).

Disability in the group of patients is apparently caused by symptoms rather than by any serious inability of the lungs or cardiovascular system to perform adequately. There is a large neurotic component in the symptoms of the disabled patients. Mild symptoms referable to the lungs occur, however, even in stable individuals who have returned to full activity after exposure to phosgene. Even in the absence of serious injury to the lungs, the conscious or unconscious awareness of a disturbance in the pattern of breathing may be responsible for these complaints. In the patients with a suitable psychological predisposition, many of the neurotic complaints are focused on the pulmonary symptoms, which are magnified and extended to the point of complete disability, since the patients are unwilling to attempt any activity for fear of precipitating the very disturbing and even terrifying symptoms. The symptoms in such patients may be partly those of an anxiety neurosis, but still resemble closely the symptoms produced by exposure to phosgene.

Sudden grave exposure to phosgene obviously resulted in great psychic trauma and was very demoralizing. It led to a considerable degree of personality disorganization and to the exaggeration of latent neurotic trends, brought out by this personal stress, which also highlighted socio-economic factors. As the acute anxiety subsided with understanding interviewing and management, there was a shift of emphasis from concern about the physiological manifestations of anxiety to personal issues and themes in the lives of these patients. It may be said that this transition, when accomplished, was of considerable therapeutic value.

\section{CONCLUSIONS}

1. Objective studies of pulmonary function have been carried out in six patients from 3 to 14 months after exposure to phosgene, which in 4 patients resulted in acute pulmonary edema and emphysema.

2. After 3 weeks following exposure, physical examinations and roentgenograms revealed no definite evidence of disease of the lungs, but the patients complained of symptoms like those reported in phosgene casualities during World War I.

3. The rapid, shallow breathing, described by Haldane, Meakins, and Priestley, was regularly observed but was not associated with a disturbance of intrapulmonary mixing of gases sufficient to lead to anoxemia.

4. Breathing oxygen did not alter the pattern of respiration and did not afford consistent relief of symptoms.

5. Objective changes of pulmonary function were consistently observed but varied in type and severity, and could not be correlated with the seriousness of initial injury or chronic symptoms.

6. The severity of chronic symptoms and the associated disability were closely related to the patients' psychological reactions.

7. A possible explanation of these observations would be that the injury initiated changes in the lungs and a uniform pattern of symptoms, which in certain individuals were sufficiently disturbing to produce disability.

\section{APPENDIX}

Clinical summaries and data on pulmonary and circulatory function studies. Case histories of patients 1 through 6 are given below. The clinical course and laboratory findings of cases 1,2 , 
3, 4 and 5 are summarized in Figures $1 \mathrm{~A}$ through $5 \mathrm{~A}$.

The results of the pulmonary function studies on each patient are presented in Figures $1 \mathrm{~B}, 1 \mathrm{C}$, $1 \mathrm{D}$ through $5 \mathrm{C}, 6 \mathrm{~A}, 6 \mathrm{~B}$ and in Tables IA, IB through IVB, VA, VB, VC through VIC.

The number of each figure and table corresponds to the case number listed in Table I.

Legends for figures on intrapulmonary mixing of gases. The data on each patient are presented in two ways (see Methods).

(a) Figures 1C, 2C, 3C, 4C, 5B, 6A. These figures present the difference between predicted nitrogen concentrations and observed nitrogen concentrations, and between predicted nitrogen concentrations and calculated nitrogen concentrations for each number of breaths. The ordinates represent differences in nitrogen concentration

\section{Residual Air \% of Total Capacity}

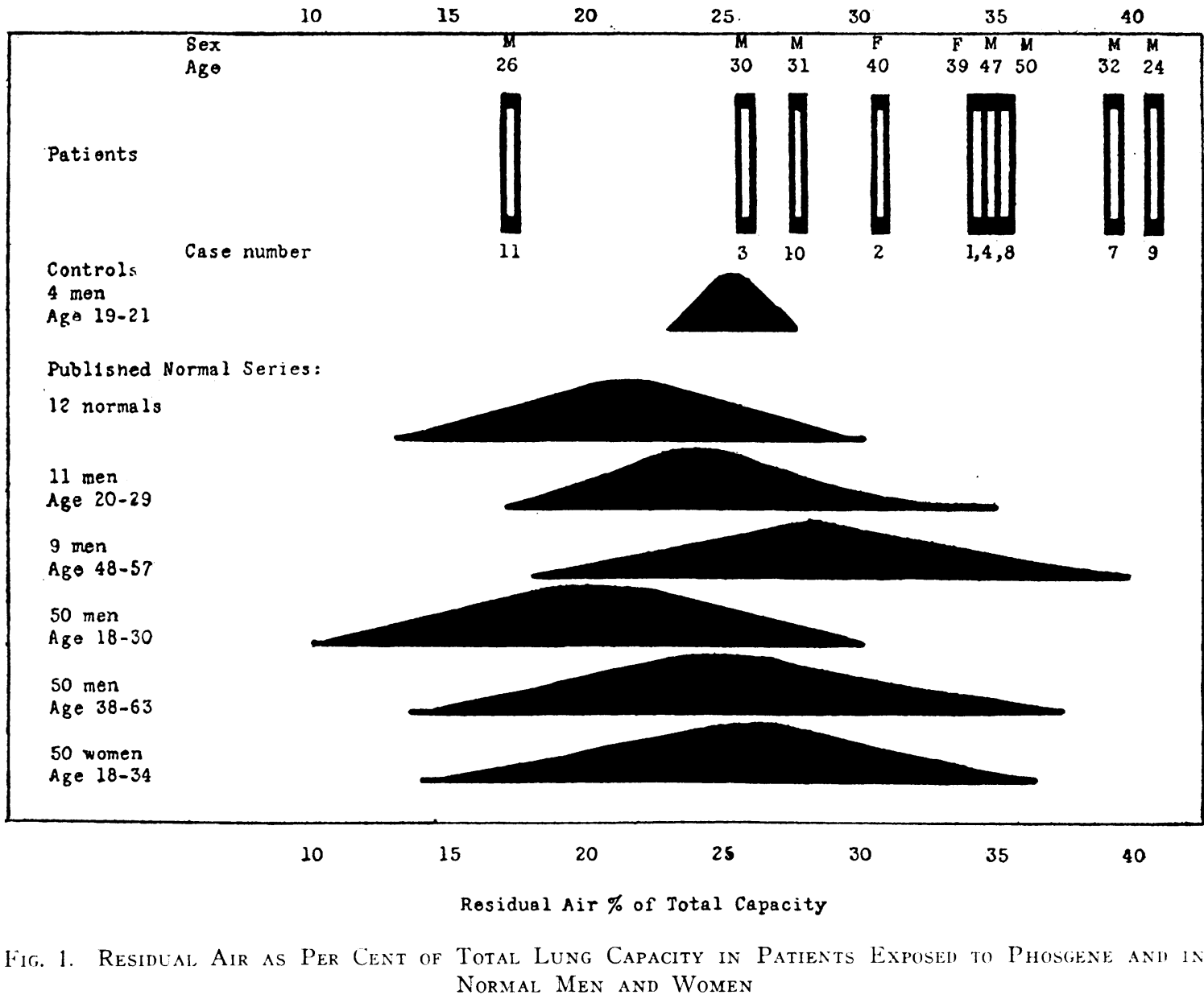

Each block at the top of the chart represents a patient exposed to phosgene. The number under each block designates the patient as referred to in the case history, with the exception that numbers $7,8,9,10,11$ refer to cases $1,2,3,4,5$ in the group of patients with chronic exposure to phosgene (34).

In descending order are curves which represent the mean and range of variation observed in different laboratories: 4 men, 19-21 years, present study, open circuit method of Darling et al (19); 12 normals, age not specified, open circuit method of Darling et al, by Cournand et al (20); 11 men (20-29 years) and 9 men (48-57 years), modified Christie method (closed circuit), by Robinson (23); last three curves, modified Christie method (closed circuit), by Kaltreider et al (21). 
RESIDUAL EFFECTS OF PHOSGENE POISONING. I

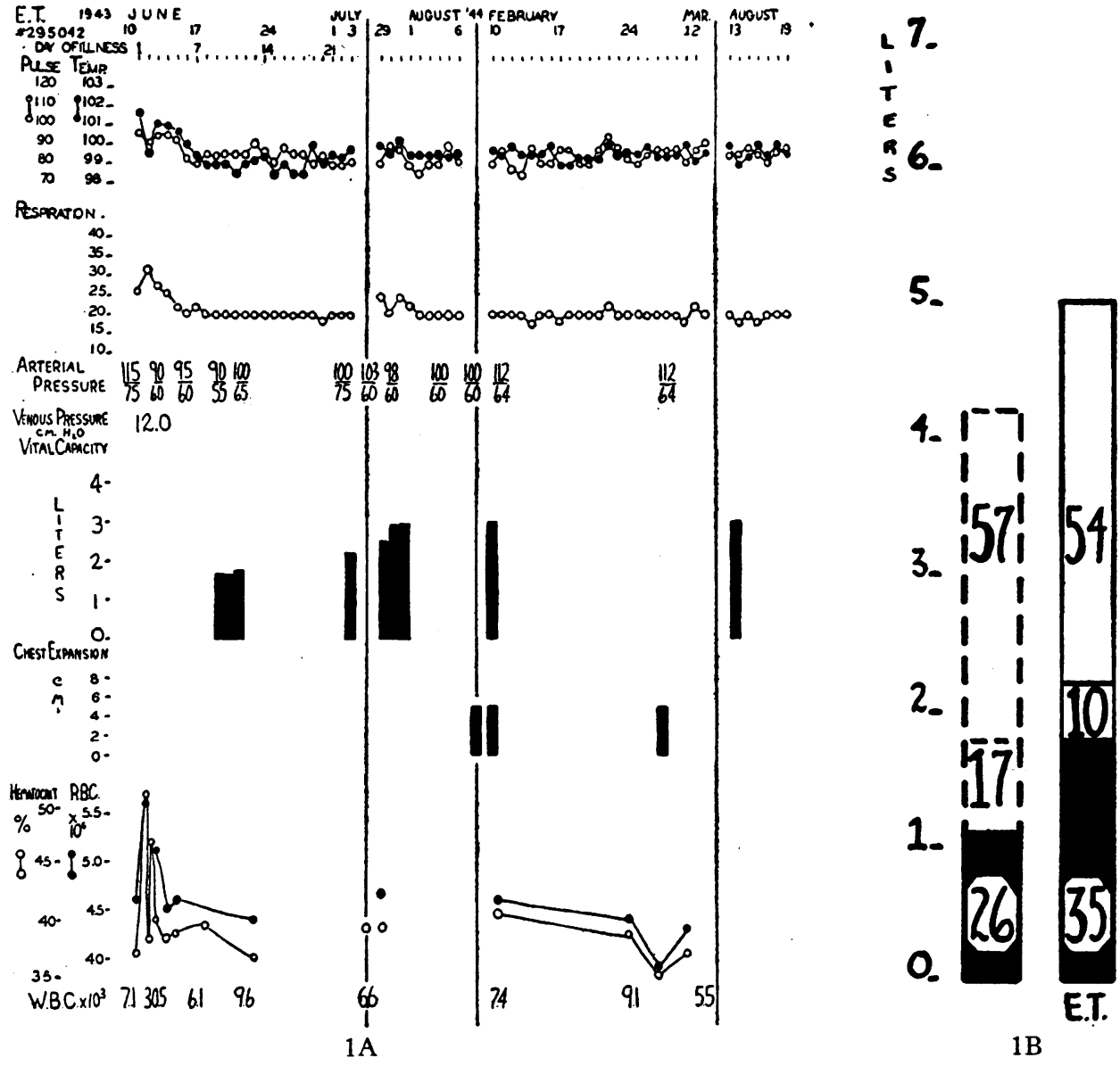

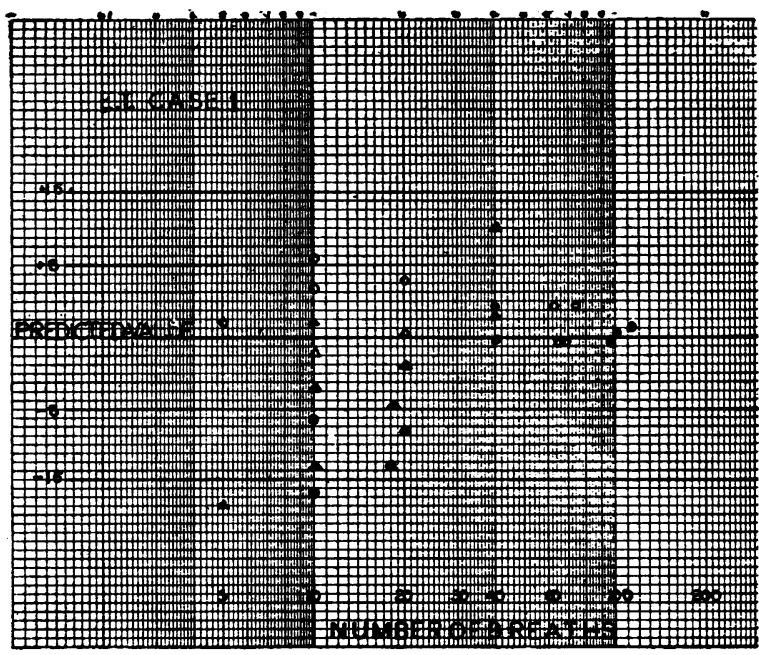

1C

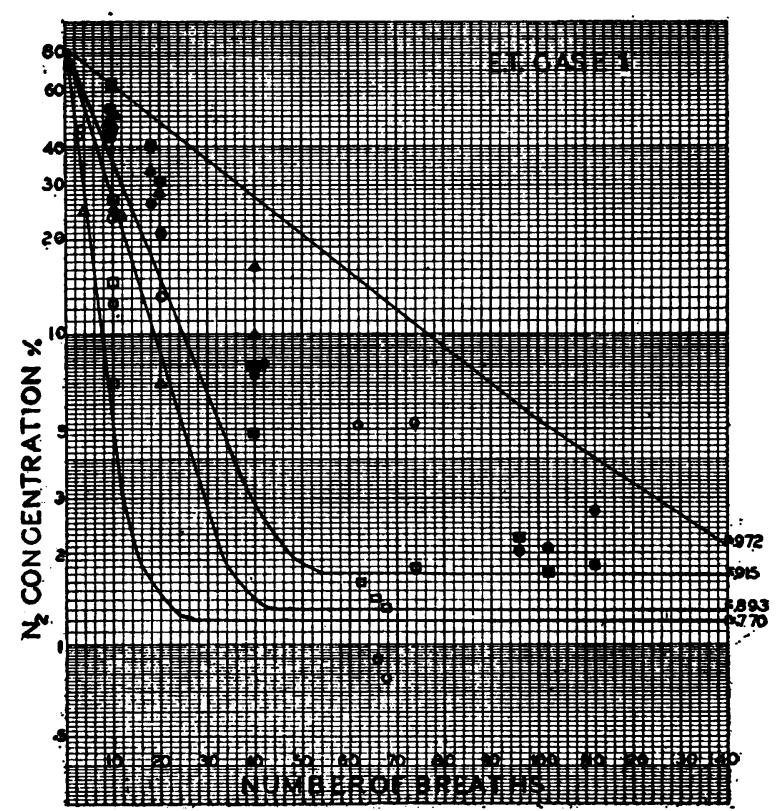

1D

Fig. 1A. Clinical Course; 1B. Subdivisions of Lung Volume; 1 C and 1D. Intrapulmonary Mixing of GASES-Tmal AIR : 220-440 ml. generally $325 \mathrm{ml}$.) voluntarily deepened : 480-810 ml. (generally $600 \mathrm{ml}$.). DeAD Space: $182 \mathrm{ml}$. (Tidal Air below $400 \mathrm{ml}$.), $224 \mathrm{ml}$. (Tidal Air above $400 \mathrm{ml}$.). 
from the predicted value which is represented by the line passing through the zero point. The abscissae represent the number of breaths.

Solid circle $\bullet=$ observed alveolar nitrogen predicted nitrogen concentration.

Solid triangle $\Delta=$ calculated nitrogen - predicted nitrogen concentration. Open circle 0 and open triangle $\Delta$ represent similar nitrogen concentration differences during voluntary deep breathing. ${ }^{5}$

5 Comparisons between predicted, observed, and calculated levels of nitrogen remaining in the lungs after a measured number of breaths of 100 per cent oxygen may be made. Predicted nitrogen concentration is the level which would exist in the alveolar air in the presence of theoretically perfect intrapulmonary mixing of gases. This is based on the formula derived by Darling et al.

$$
\text { 8- }
$$

$X$ - Predicted

- Observed

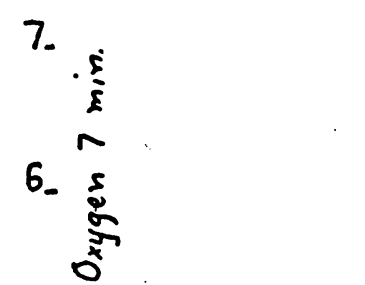

5.

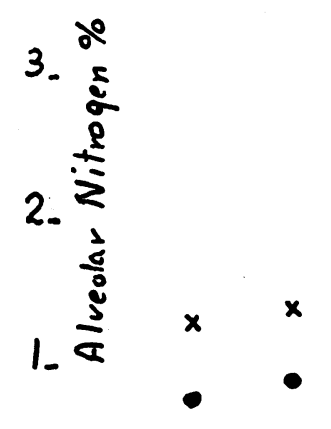

o. Nitrogen Dilution Ratio " $r$ " .775 soo $\quad 825 \quad .850 \quad 875$ 90́ 925 .9'50 975 1.000

Fig. 2. The Nitrogen Concentration of Alveolar Air After Seven Minutes of Breathing Oxygen, 6 Plotted Against the Ratio of Dilution of Functional Residual Air with Each Breath ("r") in Patients Exposed to Phosgene

The observed values are indicated by solid circles and the predicted values by crosses. During shallow breathing (large " $r$ "), there are more frequent and larger deviations from the predicted concentration than during deep breathing. This figure includes observations on the patients who had been acutely exposed to phosgene and also on the patients who had been chronically exposed to phosgene (34).

\footnotetext{
The concentration of alveolar air nitrogen after 7 minutes of breathing oxygen is another index of effectiveness of intrapulmonary mixing of gases. 2.5 volumes per cent is considered the upper limit of normal in the presence of a normal tidal air volume (20).
} 
When there is a disturbance in mixing, elimination of nitrogen from the lungs will be delayed, and calculated and observed alveolar nitrogen concentrations should exceed predicted alveolar nitrogen concentration. If there are large areas in the lungs where mixing is very poor and which contribute little or not at all to the alveolar air

(24) which includes the following factors: effective tidal air (tidal air minus respiratory dead space), functional residual air, amount of nitrogen released from the blood during the experiment, and number of breaths. Observed nitrogen concentration is the level obtained by analysis of an end-expiratory alveolar air sample. Calculated nitrogen concentration is the level which remains in the lungs. This is arrived at by subtracting the nitrogen in the expired air from the nitrogen in the functional residual air. The volume of nitrogen released from the blood during the measured number of breaths is taken into account. specimen, the calculated alveolar air nitrogen value should be greatly increased and the observed value may agree closely with the predicted value. Deviations of about 8 per cent or more in the above directions are considered indications of impaired intrapulmonary mixing of gases.

(b) Figures 1D, 2D, 3D, 4D, 5C, 6B. In these figures, the curves represent the range of values of the observed dilution ratios, $r$. When there are four curves on a figure, the two with the lowest $r$ values represent the range during voluntary deep breathing; the other two, during normal quiet breathing.

Solid squares - represent predicted nitrogen concentrations; solid circles $\bullet$, observed nitrogen concentrations; and solid triangles $\Delta$, calculated nitrogen concentrations. The open circles 0 , squares $\square$, and triangles $\Delta$ represent similar ni-

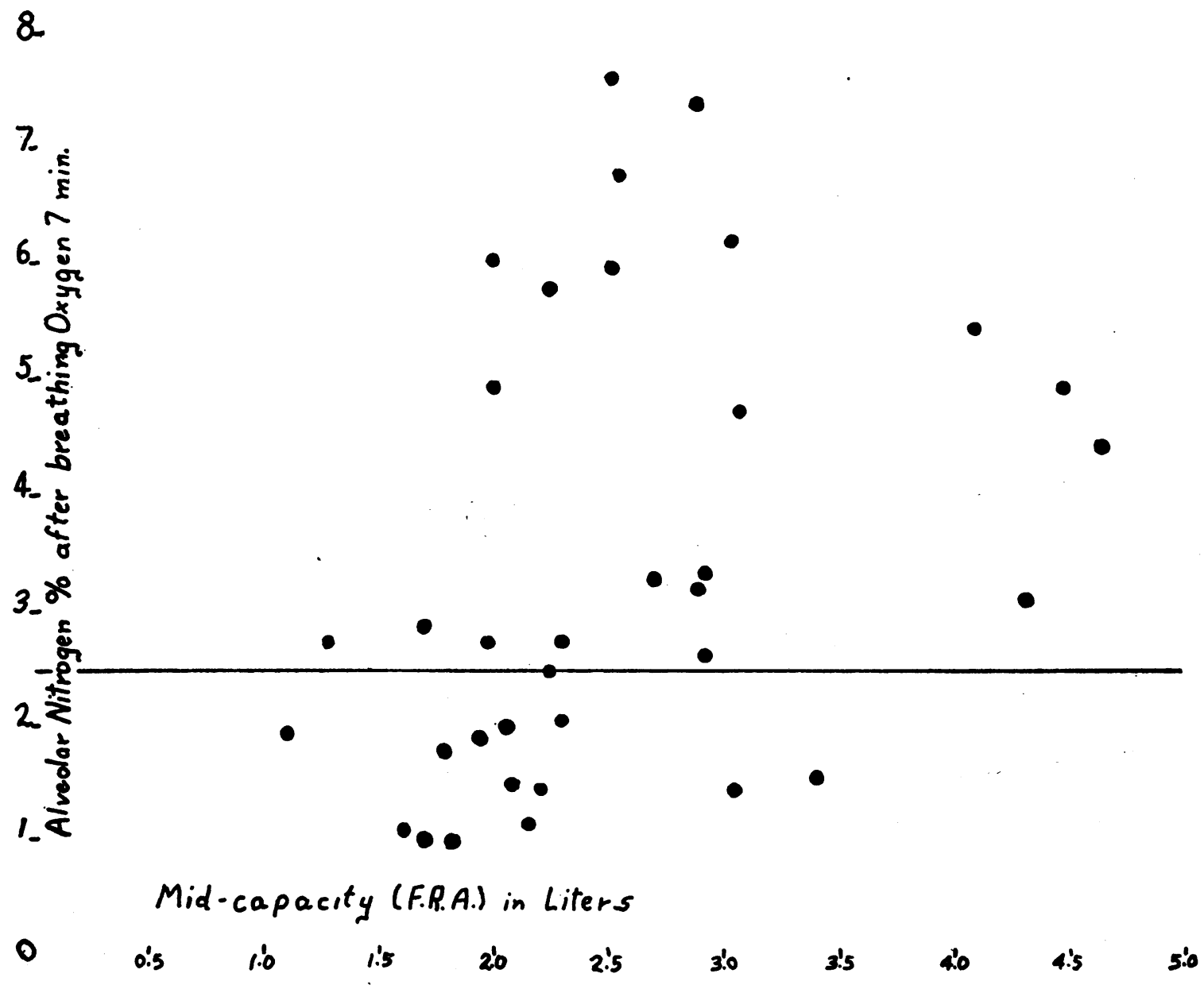

FIG. 3. 
RESIDUAL EFFECTS OF PHOSGENE POISONING. I
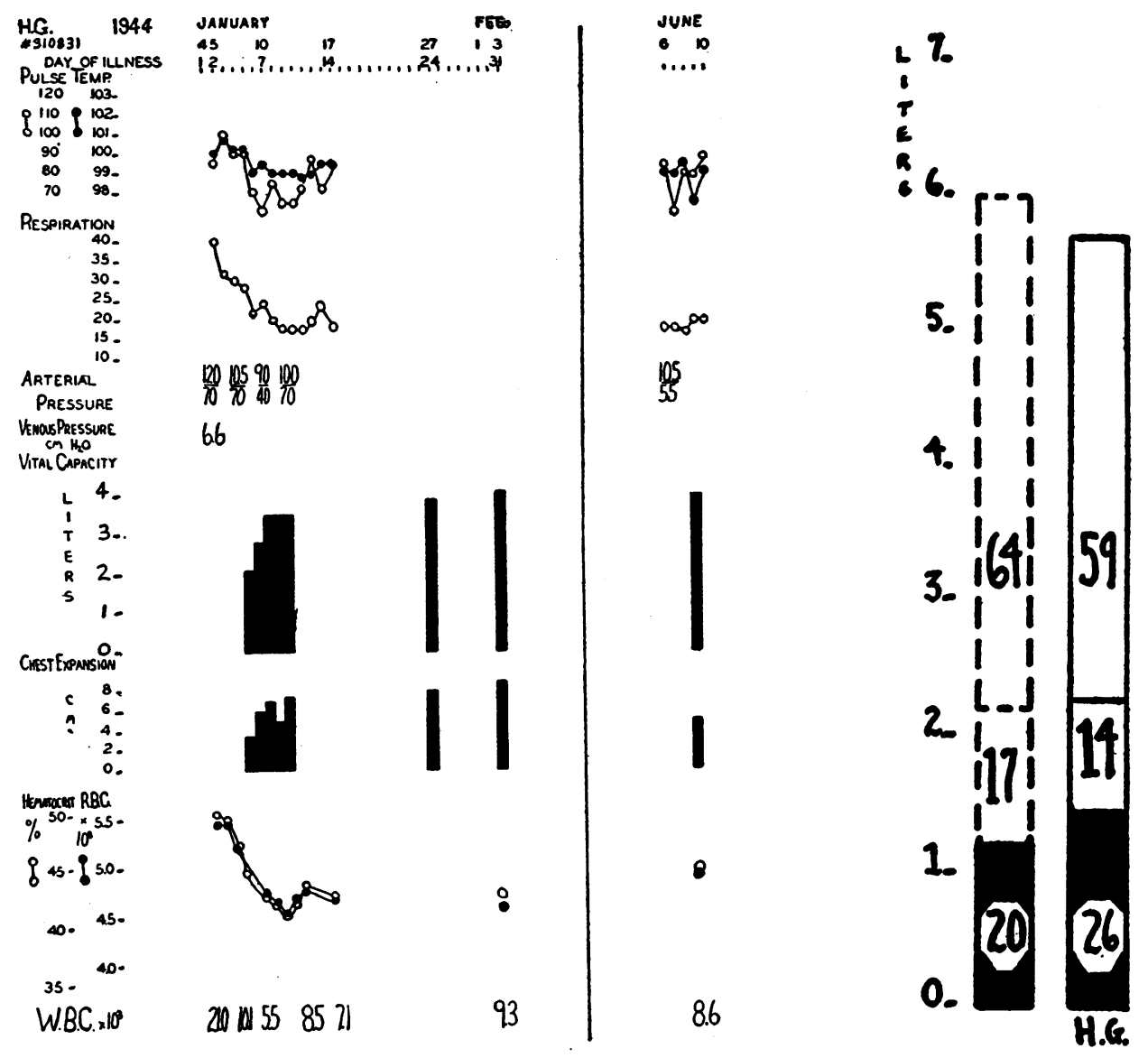

3B

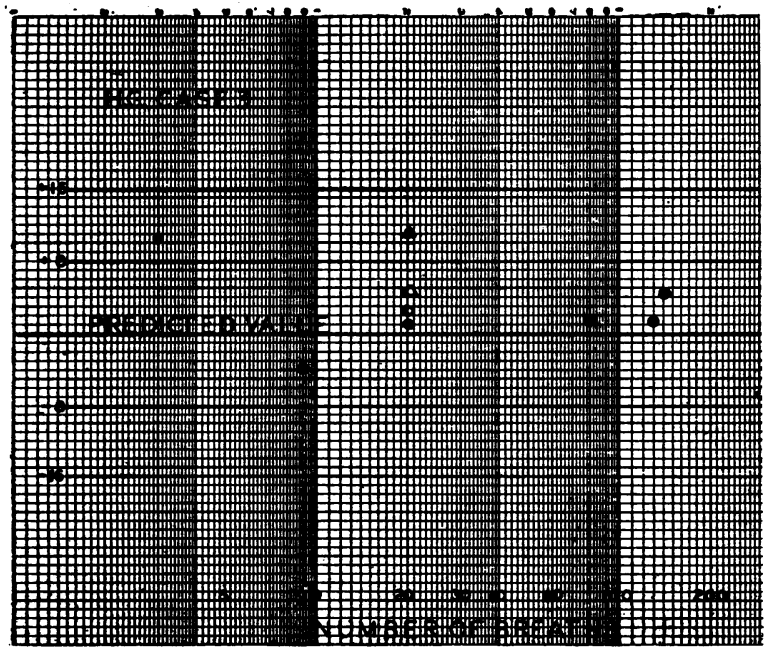

$3 \mathrm{C}$

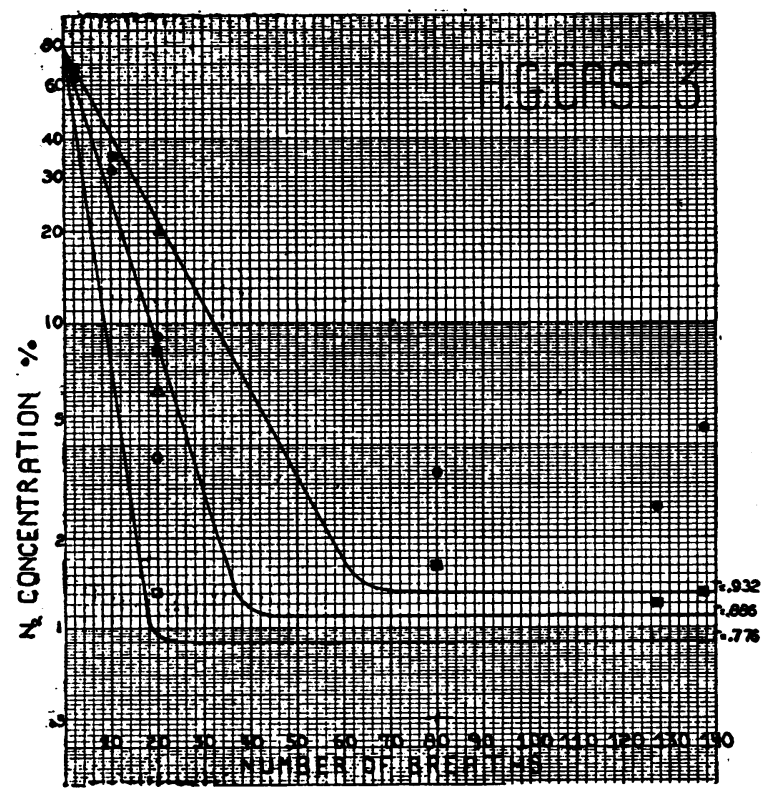

3D

Fig. 3A. Clinical Course; 3B. Subdivisions of Lung Volume; 3C and 3D. Intrapulmonary Mixing of Gases-Tidal Air: $386 \mathrm{ml} .-510 \mathrm{ml}$. (generally $400 \mathrm{ml}$.), voluntarily deepened $910 \mathrm{ml}$. Dead Space: $220 \mathrm{ml}$. 
trogen concentrations during voluntary deep breathing. $r=$ with a number following it, at the lower right end of each curve, represents the dilution ratio. ${ }^{7}$

The nitrogen concentrations marked by an arrow represent values for numbers of breaths greater than 140 .

Legend for figures on subdivisions of lung volume (Figures 1B, 2B, 3B, 4B). The values obtained for each patient are compared with the normal values of Kaltrieder et al for individuals of the same age and sex (21) expressed in absolute volumes.

The column with initials below it represents the observed total lung volume for each patient. The column drawn in broken lines represents the predicted values for the individual (21). Each column is divided into segments which represent the per cent of the total lung volume which each subdivision comprises. The white area indicates the residual air, and the black area above it, the vital capacity. The lower segment of the vital capacity indicates the reserve air; the upper segment, the complementary air.

Legends for tables IA through VIC. In the tables dealing with exercise studies, work is expressed both as foot pounds (ft.-lb.) and kilogram meters (kgm.-m.).

In the tables dealing with arterial blood oxygen tension studies the values in parentheses under arterial blood oxygen tension represent the range of generally three, occasionally two, four, or five determinations by the direct method on the same sample of blood. The value preceding the parentheses is the average of these determinations.

Carbon dioxide tension $\mathrm{mm}$. $\mathrm{Hg}$ arterial blood direct indicates the level of carbon dioxide tension in millimeters of mercury by the direct method (27).

Case 1 (E. T., Female, Age 38, Record No. 295042).

Height $160 \mathrm{~cm}$., Weight $46.3 \mathrm{kgm}$., Surface Area $1.44 \mathrm{M}^{2}$.

The patient had been working in the phosgene plant for about six months when her face was accidentally sprayed with liquid phosgene at about 10:15 a.m., June 11,1943 . Within a few hours she had developed signs of bilateral pulmonary edema and acute emphysema (Fig-

7 The dilution ratio, $r$, represents the rate of dilution of nitrogen in the functional residual air per effective breath (tidal air minus respiratory dead space) of 100 per cent oxygen. ure 1A). She was treated with oxygen inhalation under atmospheric and also positive expiratory pressure. By the third day, June 13 , she had definitely improved. On the fourth day, June 14, a roentgenogram of the lungs still exhibited diffuse mottling throughout both upper lobes and the right lower lobe. On the seventh day, June 17 , the lungs were clear on physical examination and a roentgenogram of the lungs appeared normal on the twelfth day, June 22 .

Convalescence was complicated by complaints of aching pain in the left chest and shortness of breath on walking a few steps. In spite of these symptoms her physical condition improved and she was discharged to her home on July 3, 22 days after the accident.

COURSE FOLLOWING FIRST ADMISSION TO THE HOSPITAL: During the nineteen months since the patient inhaled phosgene she has entered the hospital for observation on four occasions (Figure 1A).

She has complained of tiredness, weakness, marked shortness of breath, and palpitation on climbing one flight of steps, accompanied by sensation of a tight band around the lower part of the chest, weakness of the left side of the body with hyperesthesia and hyperalgesia, nervousness when amongst people, and nightmares. There has frequently been noted tenderness of the trapezius, pectoral, biceps and shoulder muscles, and over the cardiac impulse. Tolerance for moderate exercise has improved with practice. The lungs have been clear in serial teleoroentgenogram though increased aeration of the lower $1 / 3$ of the lung fields has appeared to develop.

PSYCHIATRIC SUMMARY : E. T. is a rather timid, insecure, apprehensive, and not too well adjusted married white woman, who, following exposure and a rather critically sick period, developed persistent bodily aches and pains, weakness, tiredness, and palpitation, which may well have a substantial basis physically. She does have, though, a definite neurotic background, which is highlighted by interpersonal conflicts involving especially a very difficult relationship with her husband. Their sexual adjustment is quite unsatisfactory, the family relationships are not too good, and the patient finds herself annoyed and irritated by the activities of her children. Since the accident she has found it impossible to continue with her regular program of activity, she has been unable to resume work, and there has been a definite tendency toward the development of a chronic invalid reaction, which might be characterized clinically as a psychoneurosis - an anxiety state with hypochondriacal and neurasthenic features. The emotional factors have continued to assume increasing importance, and, though not recognized consciously by the patient, compensation issues are significant.

PULMONARY FUNCTION studies: The ratio of residual air to total capacity is close to the upper limit of normal variation. The absolute volume of vital capacity is normal, but, because of the high residual air, the ratio of vital capacity to total capacity is reduced to the lower range of normal variation (Figure 1B). 

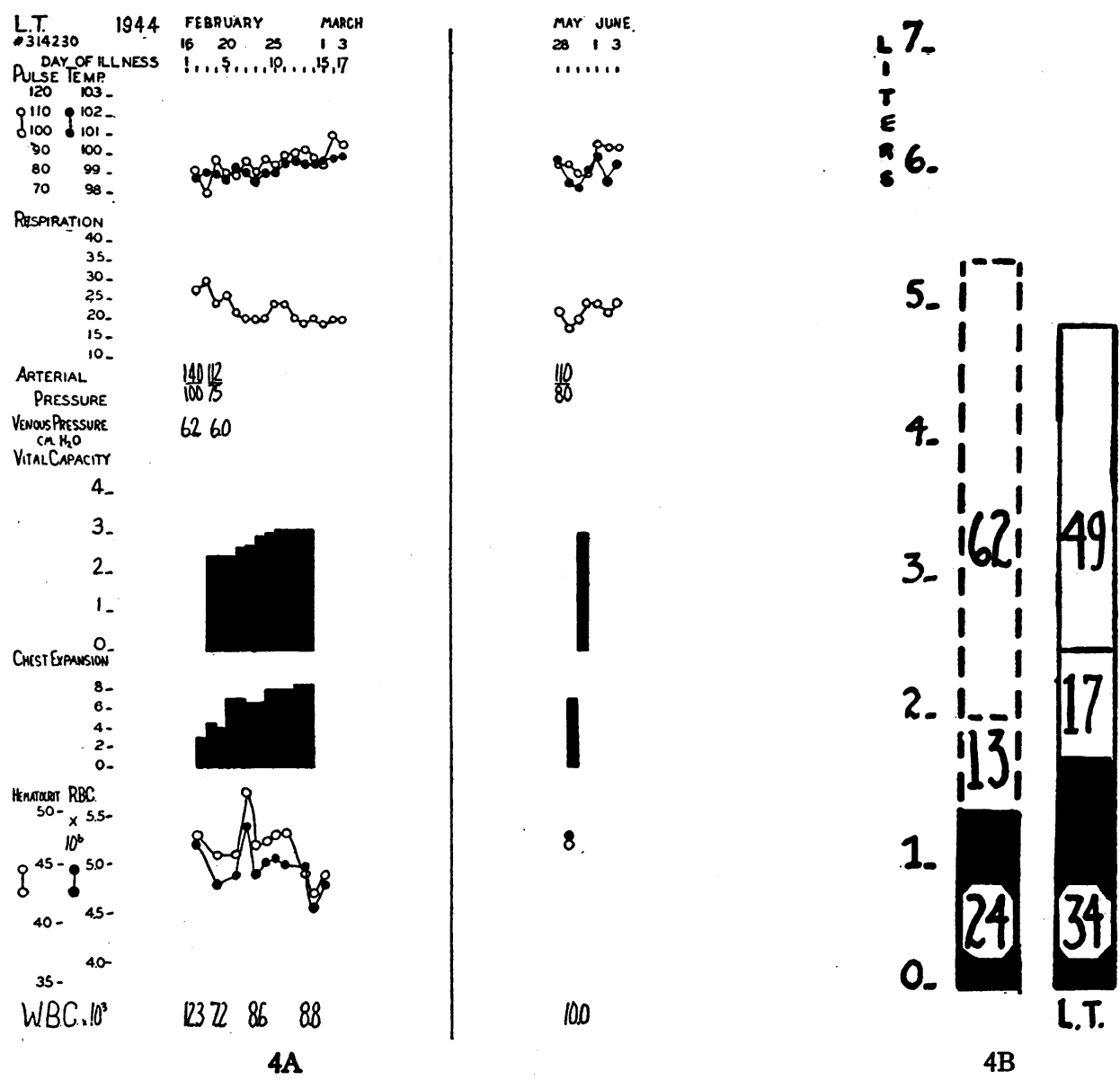

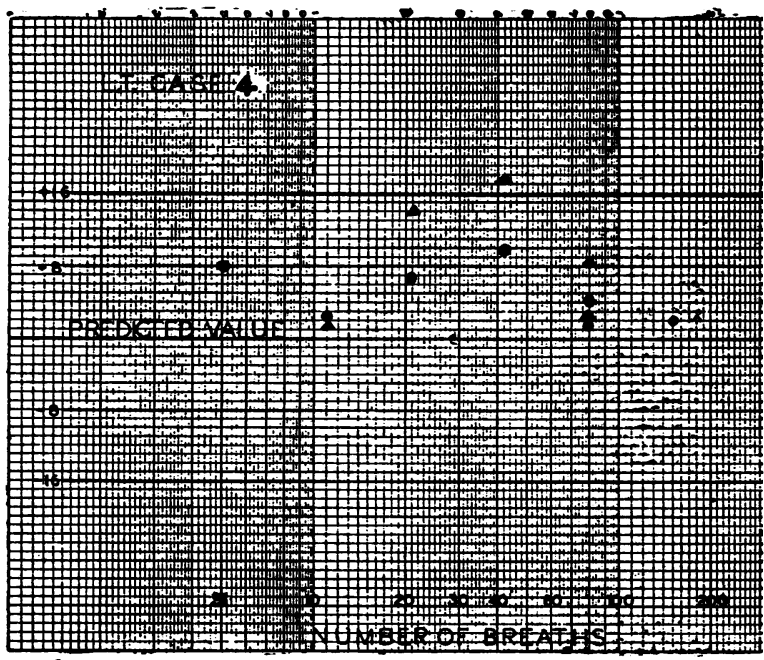

4C

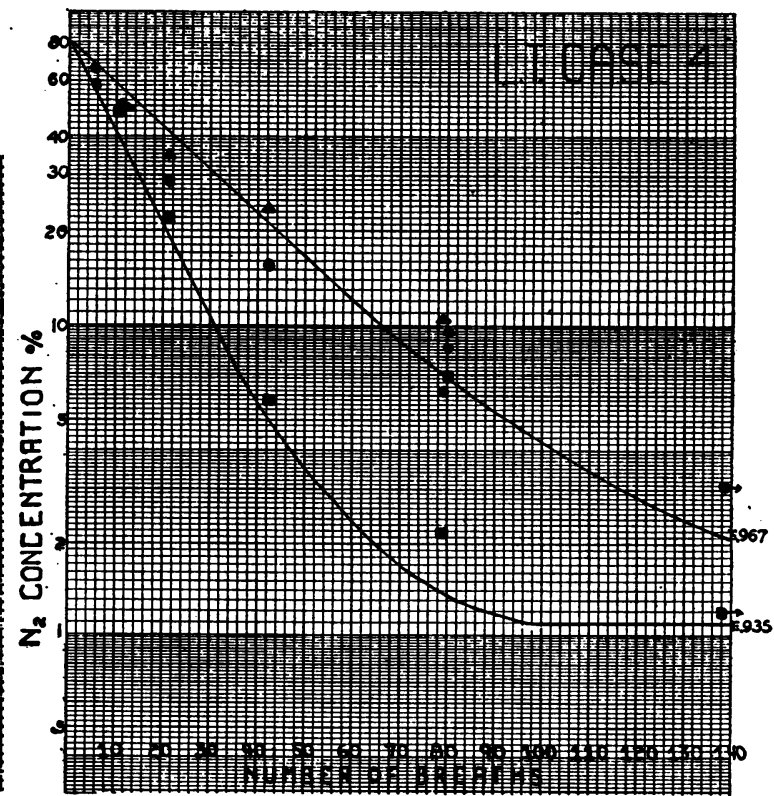

4D

Fig. 4A. Clinical Course; 4B. Subdivisions of Lung Volume; 4C and 4D. Intrapulmonary Mixing of Gases-Tidal Air: $356-457 \mathrm{ml}$. (generally $425 \mathrm{ml}$.). Dead Space : $280 \mathrm{ml}$. 
Respiratory rate and depth at rest are normal. The pattern of respiration is not altered by breathing oxygen. The minute respiratory volume during exercise increases primarily by an increase in the depth of tidal air. The alveolar air oxygen and carbon dioxide tensions are normal except for a high carbon dioxide tension occasionally (Table IA).

The nitrogen dilution rate is slow. The intrapulmonary mixing of gases is not impaired. The pulmonary emptying rate is normal (Figures 1C, 1D).

The oxygen extraction per volume of air breathed at rest is at the lower limit of normal. It rises slightly during exercise (step test) and to a greater degree during recovery. The rate of elimination of carbon dioxide is normal at rest and does not change significantly during exercise but like the oxygen uptake continues to increase during recovery (Table IA).

The arterial blood and alveolar air studies indicate that there is no disturbance in oxygen and carbon dioxide exchange in the lungs at rest and during exercise (Table IB).

The voluntary breathing capacity is 72 liters ( 94.0 per cent of the predicted value) when standing and 70 liters

TABLE IA

Respiratory pattern resting

\begin{tabular}{|c|c|c|c|c|c|c|c|c|}
\hline \multirow{2}{*}{$\begin{array}{l}\text { Date } \\
1944\end{array}$} & \multirow{2}{*}{$\underset{\text { ment }}{\text { Experi- }}$} & \multirow{2}{*}{$\begin{array}{l}\text { Reap. } \\
\text { rate }\end{array}$} & \multirow{2}{*}{$\underset{\text { air }}{\text { Tidal }}$} & \multirow{2}{*}{$\begin{array}{l}\text { Min. } \\
\text { vol. }\end{array}$} & \multicolumn{2}{|c|}{ Alveolar air } & \multicolumn{2}{|c|}{ Expired air } \\
\hline & & & & & $\mathrm{pO}_{2}$ & $\mathrm{pCO}_{2}$ & $\mathrm{O}_{2}$ & $\mathrm{CO}_{2}$ \\
\hline $\begin{array}{l}8 / 14 \\
8 / 15 \\
8 / 16\end{array}$ & $\begin{array}{l}\text { Air } \\
\mathbf{O}_{2} \\
\mathbf{O}_{2} \\
\mathbf{O}_{2} \\
\mathbf{O}_{2} \\
\text { Air } \\
\text { Air }\end{array}$ & $\begin{array}{l}\frac{12}{13.5} \\
15.5 \\
14.5 \\
15.5 \\
17\end{array}$ & $\begin{array}{l}\mathrm{ml} . \\
103 \\
\frac{103}{331} \\
353 \\
410 \\
372 \\
844\end{array}$ & \begin{tabular}{|c}
$l$. \\
4.88 \\
4.93 \\
4.47 \\
5.51 \\
5.89 \\
5.82 \\
$\mathbf{5 . 8 2}$
\end{tabular} & \begin{tabular}{|r}
94.5 \\
656.0 \\
652.0 \\
646.0 \\
6500 \\
99.8 \\
91.4
\end{tabular} & $\begin{array}{l}52.2 \\
41.0 \\
43.3 \\
41.5 \\
42.0 \\
40.7 \\
47.3\end{array}$ & 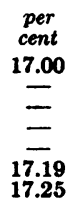 & $\begin{array}{c}\text { per } \\
\text { cent } \\
3.13 \\
= \\
= \\
2.96 \\
3.02\end{array}$ \\
\hline
\end{tabular}

Exercise *

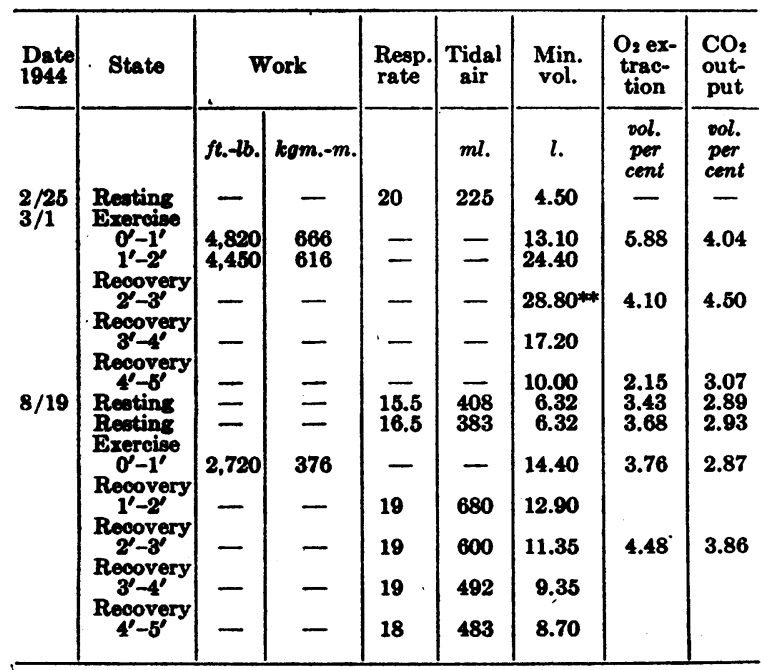

* Exercise on 3/1 was on bicycle ergometer, on 8/19 was step test.

** Dyspnea at this volume.
TABLE IB

Arterial blood studies

\begin{tabular}{|c|c|c|c|c|c|}
\hline $\begin{array}{l}\text { Date } \\
1944\end{array}$ & State & $\begin{array}{l}\mathrm{CO}_{2} \\
\text { con- } \\
\text { tent }\end{array}$ & $\begin{array}{c}\mathrm{O}_{2} \\
\text { con- } \\
\text { tent }\end{array}$ & $\underset{\text { capa- }}{\mathrm{O}_{2}}$ & $\begin{array}{l}\text { Satu- } \\
\text { ration }\end{array}$ \\
\hline & & $\begin{array}{c}\text { vol. } \\
\text { per cent }\end{array}$ & porl. & $\begin{array}{c}\text { vol. } \\
\text { per cent }\end{array}$ & $\begin{array}{l}\text { per } \\
\text { cent }\end{array}$ \\
\hline $2 / 18$ & Room air & - & 14.9 & 15.5 & 95.6 \\
\hline $8 / 19$ & Uxygen & 53 & $\begin{array}{l}10.4 \\
15.7\end{array}$ & $\begin{array}{l}10.2 \\
16.2\end{array}$ & 101.0 \\
\hline & Room air-recovery * & 47.9 & 16.6 & 17.4 & 95.5 \\
\hline
\end{tabular}

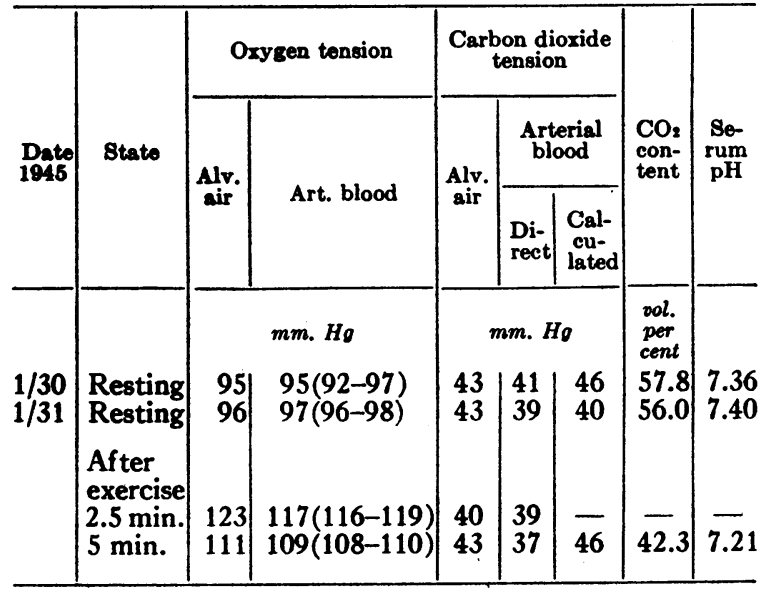

* Within first minute after step test.

(101.7 per cent of the predicted value) when recumbent. Breath-holding time is normal. The results of postural tests on a tilt table are normal. The cardiac output is 1.54 liters per minute per square meter body surface area. This is a normal value.

SUMMARY: A relative decrease in vital capacity and a relative increase in residual air are suggestive of early pulmonary emphysema. Ventilatory and respiratory functions of the lungs are normal.

Case 2 (L. W., Female, Age 39, Record No. 311004). Height $160 \mathrm{~cm}$., Weight $61 \mathrm{kgm}$., Surface Area $1.61 \mathrm{M}^{2}$.

The patient had been working in the phosgene plant for about $1 \frac{1}{2}$ years when she accidentally inhaled phosgene at about 6:00 p.m., January 4, 1944, by placing her head under a hood in which there was a cracked glass ampule containing $40 \mathrm{ml}$. of phosgene. There were no immediate disabling symptoms and the patient worked the remainder of the shift.

There was no history of previous inhalation of phosgene. Shortness of breath developed 6 to 8 hours after inhalation of phosgene. This symptom along with cough and expectoration of thick, yellow sputum became progressively worse during the next $1 \frac{1}{2}$ days.

The patient was brought to the Johns Hopkins Hospital at 12:30 p.m., January 6,1944, approximately 41 hours after exposure to phosgene. By then there were severe pulmonary edema, acute emphysema, partial col- 


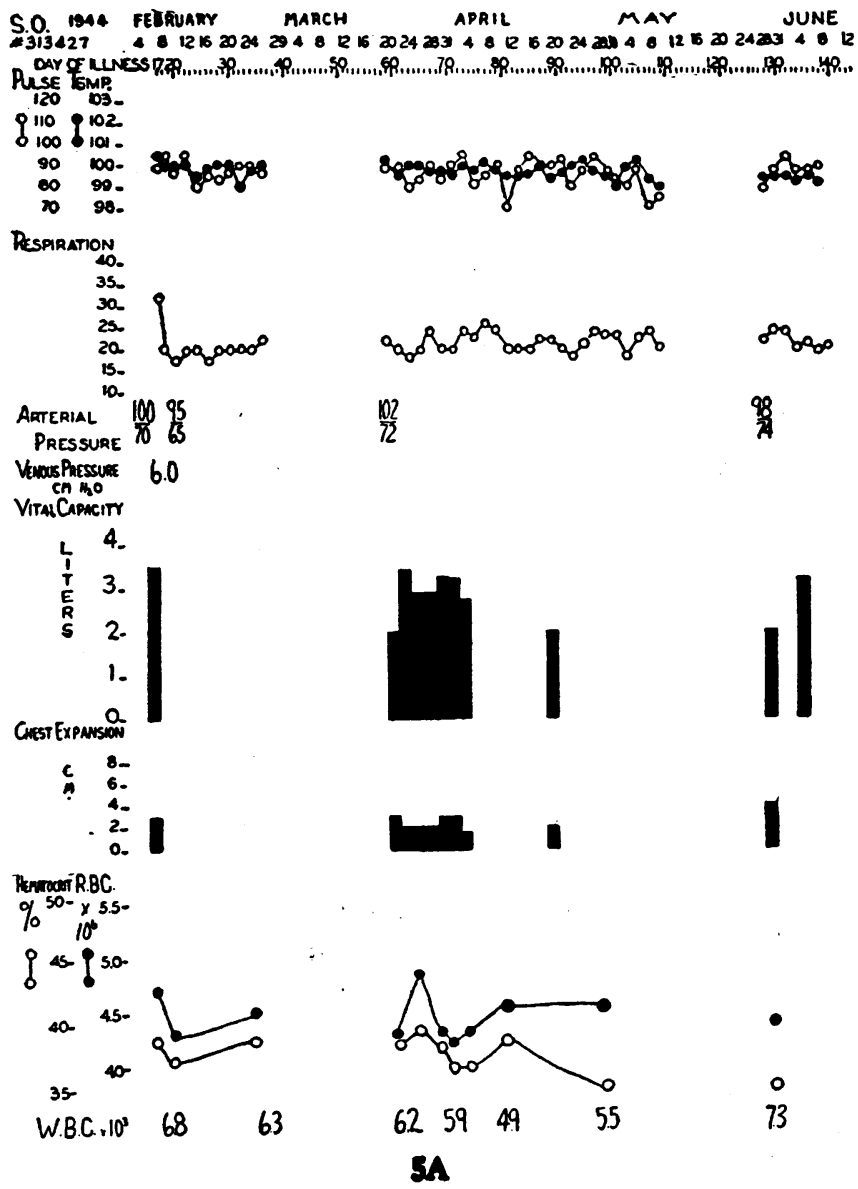

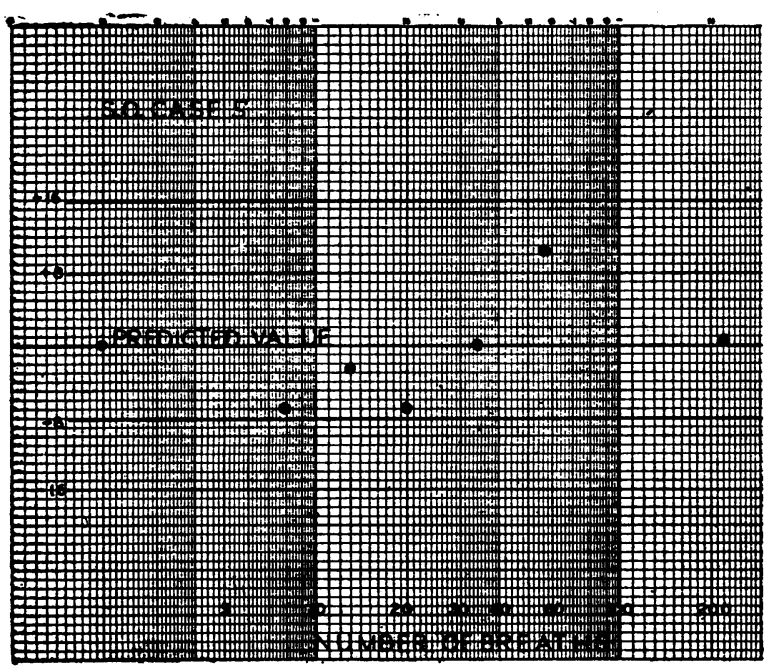

$5 B$

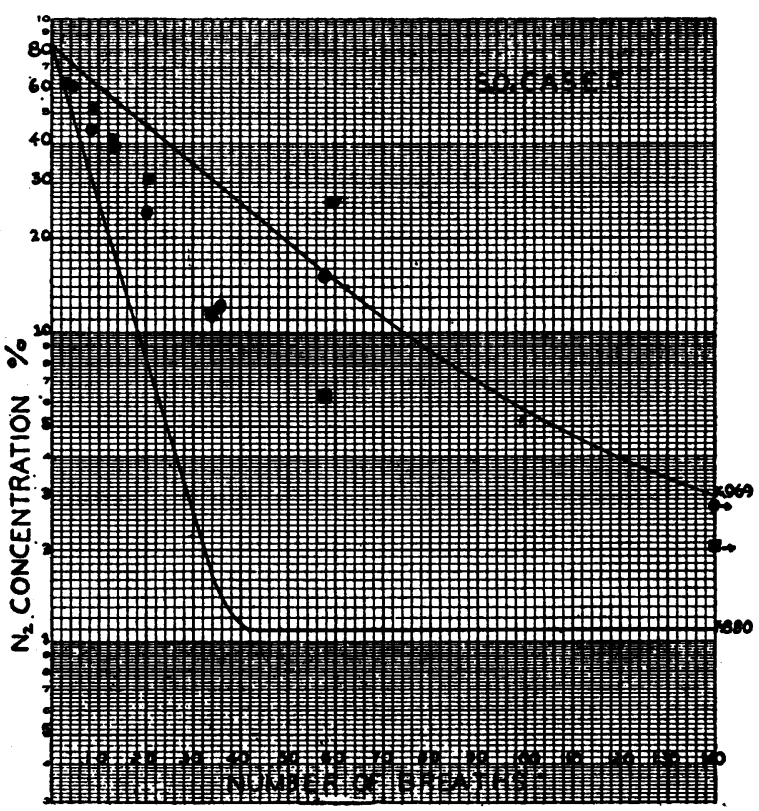

5C

Fig. 5A: Clinical Course; 5B and 5C. Intrapulmonary Mixing of Gases-Tidal Air: 225-500 ml. (generally $325 \mathrm{ml}$.). Dead Sface: $165 \mathrm{ml}$. (Tidal Air below $300 \mathrm{ml}$.), $225 \mathrm{ml}$. (Tidal Air above $300 \mathrm{ml}$.) 


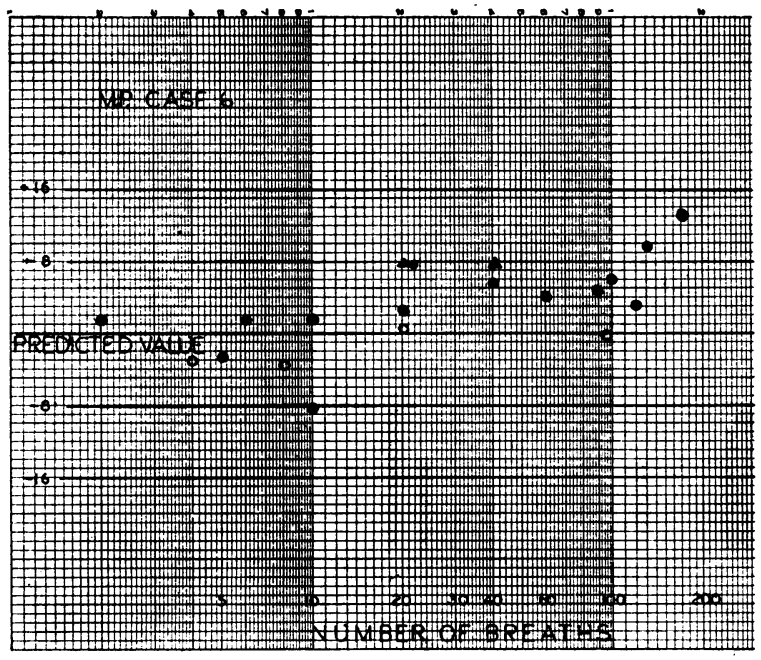

$6 \mathrm{~A}$

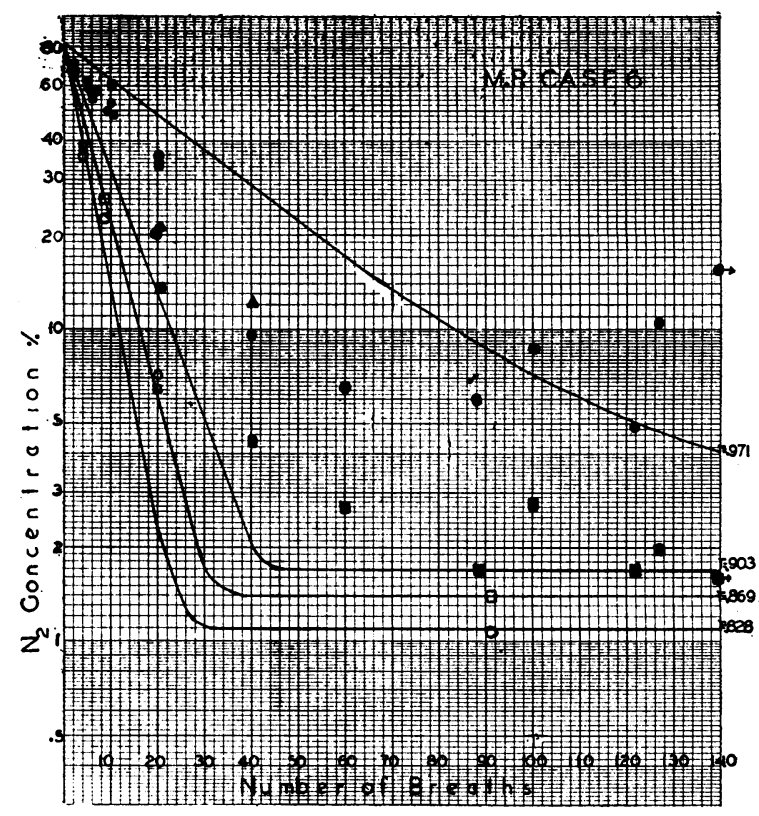

6B

Figs. 6A and 6B. Intrapulmonary Mixing of Gases-Tidal Air: 220-375 ml. (generally $275 \mathrm{ml}$.), voluntarily deeped, 512-625 ml. (generally $525 \mathrm{ml}$.). Dead Space: $161 \mathrm{ml}$. (Tidal Air below $400 \mathrm{ml}$.) ; $210 \mathrm{ml}$. (Tidal Air above $500 \mathrm{ml}$.).

lapse of the left lower lobe, marked anoxemia (arterial blood oxygen saturation 54 per cent), fever and leukocytosis (Figure 2A). Treatment consisted of continuous inhalations of 60 per cent oxygen combined with 20 minute periods of 100 per cent oxygen under 6 to $12 \mathrm{~cm}$. of water expiratory pressure.

By the morning of the third day of hospitalization the patient was comfortable and without oxygen, and abnormal lung signs were practically all gone by clinical and roentgenographic examinations.

Convalescence was rapid and without complications. At the time of discharge, January 17, 11 days after admission to the hospital, the patient experienced only slight shortness of breath and no undue fatigue after moderately severe exercise.

COURSE FOLLOWING FIRST ADMISSION TO THE HOSPITAL (Figure 2A) : A roentgenogram of the lungs taken one week following discharge from the hospital appeared normal. The patient returned to work one month following discharge from the hospital. Shortness of breath was no longer present at that time.

When last seen in June, 1945, approximately 17 months after the inhalation of phosgene, the patient was working, had no complaints, and did not exhibit any abnormalities on physical examination.

PSYCHIATRIC SUMMARY : L. W. is a 40 -year-old widow who returns to the hospital for a checkup at this time (January 25, 1945) and says she feels perfectly all right. She had her exposure in January, 1944, and after 11 days in the hospital she took 5 weeks of rest at the suggestion of Dr. Longcope. Her course since then has been quite uneventful as far as complications are concerned, and her personal adjustment has been excellent. Her previous personality structure was that of a stable, conscientious, hard-working woman. Her attitude at present is excellent and her emotional reaction quite good. She has been able to work regularly and, although she occasionally has pain in the left side of her chest, she does not get particularly distressed by it, and actually handles it quite well without any pronounced neurotic exaggeration. She has had periods of despondency, which have not been severe or particularly incapacitating. Since her husband's death some 8 years ago, she has devoted her life to the raising of her son and has been working hard enough to provide for him adequately. She is proud of her contribution to the war effort and national emergency through her work, the buying of bonds, and giving of blood. There is very little recreation in her life because her work takes up so much of her time, but she seems to thrive on it and derives a great deal of satisfaction from this work. In addition, she gets a substantial amount of satisfaction and emotional support from the good relationship with her son. She says, "I have no alternative -I have to work to support my son."

In general, she seems a quite stable individual who has made a very good personal adjustment to her traumatic experience, showing no particularly untoward emotional response, and being able to maintain a very sensible attitude. 
PULMONARY FUNCTION STUdIES: The vital capacity and the relative values of the subdivisions of the total lung volume are normal (Figure 2B).

Respiratory rate at rest is rapid, tidal air is normal, and minute respiratory volume consistently high. Breathing oxygen does not alter the pattern of respiration. During exercise, hyperventilation is even more marked than at rest because of a large increase in tidal air (Table IIA).

The nitrogen dilution rate, intrapulmonary mixing of gases, and pulmonary emptying time are normal (Figures 2C, 2D).

The maximum breathing capacity in the erect posture is reduced. It is 67.5 liters, which is 80.5 per cent of the predicted volume.

The oxygen extraction at rest per volume of air breathed falls below the normal range. The corresponding rate of carbon dioxide output is at the lower limit of normal. During exercise they both rise to well within the normal range (Table IIA).

The alveolar air oxygen tension is consistently high and the carbon dioxide tension low. This is probably due to persistent hyperventilation and is reflected by a low resting arterial blood carbon dioxide content and tension and a relatively high $\mathrm{pH}$ (Table IIB).

The arterial blood oxygen tension is considerably lower than that of the alveolar air at rest and after exercise (Table IIB). The air samples are representative of alveolar air since there is close agreement between the carbon dioxide tension of the alveolar air and arterial blood. There is no anoxemia. Breath-holding time is normal.

The results of postural tests on a tilt table are normal. The cardiac output is 1.05 liters per minute per square

TABLE IIA

\section{Respiratory pattern resting}

\begin{tabular}{|c|c|c|c|c|c|c|c|c|}
\hline \multirow{2}{*}{$\begin{array}{l}\text { Date } \\
1044\end{array}$} & \multirow{2}{*}{$\underset{\text { ment }}{\text { Experi- }}$} & \multirow{2}{*}{$\begin{array}{l}\text { Resp. } \\
\text { rate }\end{array}$} & \multirow{2}{*}{$\begin{array}{l}\text { Tidal } \\
\text { air }\end{array}$} & \multirow{2}{*}{$\begin{array}{c}\text { Min. } \\
\text { vol. }\end{array}$} & \multicolumn{2}{|c|}{ Alveolar air } & \multicolumn{2}{|c|}{ Expired air } \\
\hline & & & & & $\mathrm{pO}_{2}$ & $\mathrm{pCO}_{2}$ & $\mathrm{O}_{2}$ & $\mathrm{CO}_{2}$ \\
\hline $\begin{array}{l}6 / 14 \\
6 / 15 \\
6 / 16\end{array}$ & $\begin{array}{l}\text { Air } \\
\mathrm{O}_{2} \\
\mathrm{Air} \\
\mathrm{O}_{2} \\
\mathrm{O}_{2}\end{array}$ & $\begin{array}{l}26 \\
22 \\
28 \\
30 \\
26\end{array}$ & $\begin{array}{l}m l . \\
474 \\
535 \\
418 \\
412 \\
403\end{array}$ & $\begin{array}{c}l . \\
12.24 \\
11.93 \\
11.55 \\
12.50 \\
10.54\end{array}$ & $\begin{array}{l}115.1 \\
676.0 \\
106.5 \\
661.0\end{array}$ & $\begin{array}{l}32.8 \\
26.6 \\
35.9 \\
28.4\end{array}$ & $\begin{array}{c}\text { per } \\
\text { cent } \\
- \\
\overline{18.21} \\
-\end{array}$ & $\begin{array}{r}\begin{array}{c}\text { per } \\
\text { cent }\end{array} \\
- \\
2.27 \\
2.47 \\
2.11 \\
2.54\end{array}$ \\
\hline
\end{tabular}

Exercise *

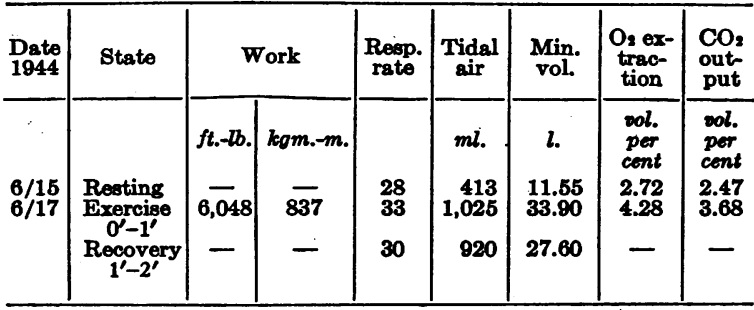

* Exercise consisted of climbing 3 flights of stairs (36 steps) in one minute; recovery period while standing.
TABLE IIB

Arterial blood studies

\begin{tabular}{c|c|c|c|c}
\hline \hline $\begin{array}{c}\text { Date } \\
1944\end{array}$ & State & $\begin{array}{c}\mathrm{O}_{2} \\
\text { content }\end{array}$ & $\begin{array}{c}\mathrm{O}_{2} \\
\text { capacity }\end{array}$ & Saturation \\
\cline { 2 - 5 } $5 / 16$ & & $\begin{array}{c}\text { vol. } \\
\text { per cent }\end{array}$ & $\begin{array}{c}\text { vol. } \\
\text { per cent }\end{array}$ & per cent \\
& & 12.5 & 12.8 & 97.8 \\
& Room air & 12.6 & 12.8 & 98.4 \\
& $\begin{array}{l}\text { Room air } \\
\text { hyperventilation } \\
\text { Oxygen }\end{array}$ & 12.8 & 12.8 & 100.0 \\
\hline
\end{tabular}

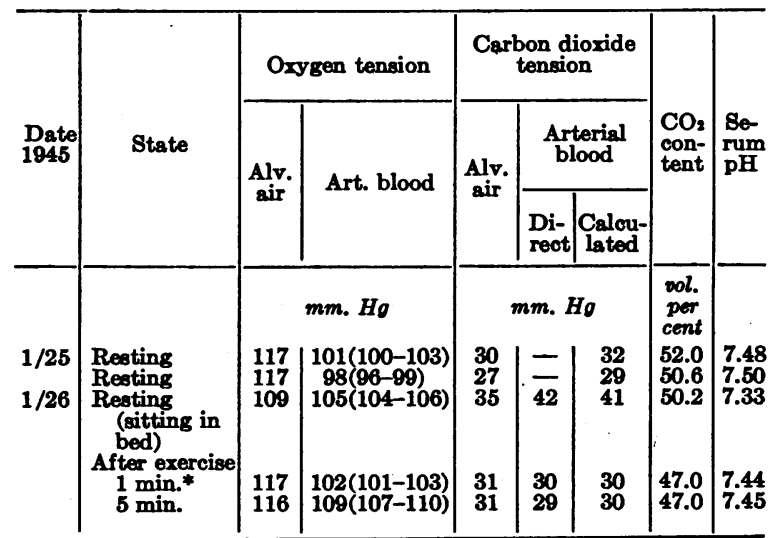

* Alveolar air sample taken while sitting in bed.

meter body surface area. This is low according to the standards used.

SUMMARY: Ventilatory function is normal except for hyperventilation characterized by a rapid respiratory rate and a normal tidal air and a reduced voluntary breathing capacity. The low oxygen, uptake and carbon dioxide output per volume of air breathed in the presence of a normal tidal air, together with the significantly higher oxygen tension in the alveolar air than in the arterial blood indicate a disturbance in respiratory function.

Case 3 (H. G., Male, Age 30, Record No. 310831). Height $177 \mathrm{~cm}$., Weight 69.7 kgm., Surface Area $1.84 \mathrm{M}^{2}$.

The patient worked as a munitions handler at Edgewood Arsenal for approximately 2 years prior to the time he was incapacitated by phosgene. During that time he had two seemingly insignificant inhalations of phosgene. There was no history of lung disease.

On January 4, 1944, at 2:30 p.m., the patient accidentally took at least two full breaths of phosgene while filling shells with phosgene. He promptly experienced marked tightness in the chest, became nauseated, and vomited. There was prompt subjective improvement from oxygen and the patient returned to work in half an hour. He worked the remainder of the day though he experienced tightness in the chest, cough with expectoration of thick yellow sputum, and dizziness. These symptoms along with respiratory distress progressed during the night.

The patient entered the Johns Hopkins Hospital on January 5, almost 24 hours following the accident (Fig- 
TABLE IIIA

Respiratory pattern resting

\begin{tabular}{|c|c|c|c|c|c|c|c|c|}
\hline \multirow{2}{*}{$\begin{array}{l}\text { Date } \\
1944\end{array}$} & \multirow{2}{*}{$\underset{\text { ment }}{\text { Experi- }}$} & \multirow{2}{*}{$\begin{array}{l}\text { Resp. } \\
\text { rate }\end{array}$} & \multirow{2}{*}{$\begin{array}{c}\text { Tidal } \\
\text { air }\end{array}$} & \multirow{2}{*}{$\begin{array}{l}\text { Min. } \\
\text { vol. }\end{array}$} & \multicolumn{2}{|c|}{ Alveolar air } & \multicolumn{2}{|c|}{ Expired air } \\
\hline & & & & & $\mathrm{pO}_{2}$ & $\mathrm{pCO}_{2}$ & $\mathrm{O}_{2}$ & $\mathrm{CO}_{2}$ \\
\hline & & & ml. & l. & & & $\begin{array}{l}\text { per } \\
\text { cent }\end{array}$ & $\begin{array}{c}\text { per } \\
\text { cent }\end{array}$ \\
\hline $\begin{array}{l}6 / 7 \\
6 / 9\end{array}$ & $\begin{array}{l}\text { Air } \\
\mathrm{O}_{2} \\
\text { Air } \\
\mathrm{O}_{2}\end{array}$ & \begin{tabular}{|l|}
22.0 \\
19.5 \\
22.0 \\
20.5
\end{tabular} & $\begin{array}{l}477 \\
440 \\
416 \\
452\end{array}$ & \begin{tabular}{|r|}
10.55 \\
8.57 \\
9.10 \\
9.26
\end{tabular} & \begin{tabular}{|l|}
100.4 \\
627.0 \\
105.0 \\
761.0
\end{tabular} & $\begin{array}{l}38.7 \\
39.8 \\
38.7 \\
38.6\end{array}$ & $\overline{\overline{17.88}}$ & $\begin{array}{l}2.60 \\
2.80 \\
2.56 \\
2.82\end{array}$ \\
\hline
\end{tabular}

Exercise *

\begin{tabular}{|c|c|c|c|c|c|c|c|c|}
\hline \multirow[t]{2}{*}{$\begin{array}{l}\text { Date } \\
1944\end{array}$} & State & \multicolumn{2}{|c|}{ Work } & $\begin{array}{l}\text { Resp. } \\
\text { rate }\end{array}$ & $\begin{array}{c}\text { Tidal } \\
\text { air }\end{array}$ & $\begin{array}{l}\text { Min. } \\
\text { vol. }\end{array}$ & $\begin{array}{c}\mathrm{O}_{2} \text { ex- } \\
\text { trac- } \\
\text { tion }\end{array}$ & $\begin{array}{l}\mathrm{CO}_{2} \\
\text { out- }\end{array}$ \\
\hline & & $f t .-l b$. & kgm.-m. & & $m l$. & $l$. & $\begin{array}{l}\text { vol. } \\
\text { per }\end{array}$ & $\begin{array}{l}\text { ool. } \\
\text { per }\end{array}$ \\
\hline \multirow[t]{2}{*}{$\begin{array}{l}6 / 9 \\
6 / 10\end{array}$} & Resting & $19, \overline{800}$ & $2, \overline{740}$ & $\begin{array}{l}22 \\
48\end{array}$ & $\begin{array}{l}413 \\
874\end{array}$ & $\begin{array}{l}9.10 \\
41.80^{* * *}\end{array}$ & $\begin{array}{l}3.05 \\
2.33\end{array}$ & $\begin{array}{l}2.56 \\
3.54\end{array}$ \\
\hline & Recovery & - & - & 37 & 950 & 35.20 & - & - \\
\hline \multirow[t]{3}{*}{$6 / 10$} & Exercise & 6,240 & 864 & 28 & 836 & 23.40 & - & 一 \\
\hline & Exercise & 6,900 & 954 & 32 & 860 & 27.50 & 5.23 & 4.54 \\
\hline & $\underset{2^{\prime}-3^{\prime}}{\text { Exercise }}$ & 7,000 & 968 & 31 & 994 & 30.80 & - & - \\
\hline
\end{tabular}

* On bicycle ergometer.

** Dyspnea.

ure $3 \mathrm{~A})$. By then there were pulmonary edema, acute emphysema, marked anoxemia (arterial blood oxygen saturation 53 per cent). The level of arterial blood pressure was $120 / 70$. There were no signs of heart failure. Treatment consisted of continuous inhalations of 60 per cent oxygen under atmospheric pressure with 20minute periods of 100 per cent oxygen under 6 to $12 \mathrm{~cm}$. of water expiratory resistance.

By the morning of the third day, January 7 th, the patient had definitely improved. On the fifth day, January 9th, he no longer required oxygen and on the sixth day, the lungs were clear. Convalescence was rapid and he was discharged on the thirteenth day, January 17, capable of performing moderately heavy work without any difficulty.

COURSE FOLLOWING FIRST ADMISSION TO THE HOSPITAL (Figure 3A): The patient returned to work as a painter at Edgewood Arsenal three weeks after discharge. $\mathrm{He}$ did not experience any limitation of physical ability.

When last seen in January, 1945, approximately one year after accidental exposure to phosgene, he was working steadily, was in good health, and did not exhibit any new physical findings.

PSYCHIATRIC SUMMARY: H. G. is a likeable, friendly, but very simple person. $\mathrm{He}$ is stable, has a good work record which he points to with pride, and he is conscientious. Though his exposure was followed by quite definite bodily distress, he experienced a very satisfactory emotional reaction and, largely as a result of his feeblemindedness, which may well have prevented his being able to appreciate fully the seriousness of the situation, he was able to make a very good personal adjustment char- acterized by an agreeable, enthusiastic attitude, and an anxiousness to return to his former work to prove that he could take it.

PULMONARY FUNCTION STUDIES: The vital capacity is normal. The ratio of residual air to total capacity is normal (Figure 3B).

The rate of breathing is rapid; tidal air is at the lower limit of the normal range. The minute volume is high. The expired air carbon dioxide content is low and oxygen content high. The composition of the alveolar air is normal. During moderate exercise, depth of breathing increases and the carbon dioxide output and oxygen extraction rise (Table IIIA).

The rate of dilution of lung nitrogen is normal. The data concerning intrapulmonary mixing of gases are insufficient to draw definite conclusions, but several points are suggestive of impaired mixing (Figures 3C, 3D).

The oxygen saturation of the arterial blood at rest is 96.4 per cent (Table IIIB). Oxygen and carbon dioxide tension studies in arterial blood and alveolar air indicate that there is no disturbance in gaseous exchange in the lungs at rest and during exercise.

The voluntary breathing capacity in the erect posture is impaired. It is 81.8 liters which is only 62.7 per cent of the predicted value. Breath-holding is normal in duration.

Postural change on a tilt table produces no abnormal circulatory or respiratory response. The cardiac output is 1.41 liters per minute per square meter body surface area. This is a normal value.

SUMMARY: There is a disturbance in the ventilation as indicated by a low voluntary breathing capacity, a rapid respiratory rate, and suggestive evidence of impaired intrapulmonary mixing of gases. Respiratory function of the lungs is normal.

TABLE IIIB

Arterial blood studies

\begin{tabular}{c|c|c|c|c}
\hline \hline Date 1944 & State & O2 content $^{*}$ & Os capacity & Saturation \\
\cline { 2 - 4 } $6 / 8$ & Resting & $\begin{array}{c}\text { vol. per cent } \\
17.7\end{array}$ & $\begin{array}{c}\text { vol. per cent } \\
18.4\end{array}$ & $\begin{array}{c}\text { per cent } \\
96.4\end{array}$ \\
\hline
\end{tabular}

\begin{tabular}{|c|c|c|c|c|c|c|c|c|}
\hline \multirow{3}{*}{$\begin{array}{l}\text { Date } \\
1945\end{array}$} & \multirow{3}{*}{ State } & \multicolumn{2}{|c|}{ Oxygen tension } & \multicolumn{3}{|c|}{$\underset{\text { Carbon dioxion }}{\text { Cade }}$} & \multirow{3}{*}{$\begin{array}{l}\mathrm{CO}_{2} \\
\text { con- } \\
\text { tent }\end{array}$} & \multirow{3}{*}{$\begin{array}{c}\text { Se- } \\
\text { rum } \\
\text { pH }\end{array}$} \\
\hline & & \multirow{2}{*}{$\underset{\text { air }}{\text { Alv. }}$} & \multirow{2}{*}{ Art. blood } & \multirow{2}{*}{ Alv. } & \multicolumn{2}{|c|}{$\begin{array}{c}\text { Arterial } \\
\text { blood }\end{array}$} & & \\
\hline & & & & & $\begin{array}{l}\mathrm{Di}- \\
\text { rect }\end{array}$ & $\begin{array}{l}\text { Cal- } \\
\text { cu- } \\
\text { lated }\end{array}$ & & \\
\hline \multirow{4}{*}{$1 / 12$} & \multirow{4}{*}{$\begin{array}{l}\text { Resting } \\
\text { Resting } \\
\text { After } \\
\text { exercise } \\
1 \text { min. }\end{array}$} & & mm. $\mathrm{Hg}$ & \multicolumn{3}{|c|}{ mm. Ho } & $\begin{array}{l}\text { vol. } \\
\text { per } \\
\text { cent }\end{array}$ & \\
\hline & & 96 & $96(94-98)$ & 42 & 1 - & 42 & 57.8 & 7.39 \\
\hline & & 99 & $99(97-102)$ & 43 & 一 & & - & \\
\hline & & 125 & $125(122-128)$ & 38 & - & 43 & 45.7 & 7.27 \\
\hline
\end{tabular}


Case 4 (L. T., Male, Age 48, Record No. 314230). Height $174 \mathrm{~cm}$., Weight $68.1 \mathrm{kgm}$., Surface Area $1.81 \mathrm{M}^{2}$.

The patient has been under the care of his private physician since 1938 because of inconstant aching pain in the left anterior chest, not related to breathing or exertion. Cause for the pain has not been found.

$\mathrm{He}$ worked in the chlorine and phosgene plants of Edgewood Arsenal for nearly two years before he was admitted to the Johns Hopkins Hospital following accidental inhalation of phosgene.

On November 15, 1942, the patient had a non-disabling exposure to chlorine. On December 23, 1943, he accidentally took a short breath of phosgene while loading shells in a box car. He soon had a choking sensation, coughed frequently, expectorated tenacious white phlegm, became nauseated, vomited, and felt dizzy. He did not seek medical attention and rested at home for the next 10 days. On returning to work there still were some cough, expectoration, and a sensation of tightness in the chest.

On February 16, 1944, he again accidentally took one or two breaths of phosgene. The immediate symptoms were similar to those following the first exposure but more intense. He sought medical attention for the symptoms. The next morning on reporting to work he was referred to Johns Hopkins Hospital (Figure 4A).

Here it was noted that the patient had acute pulmonary emphysema, edema of the base of each lung, and edema of the pharynx. There was no heart failure.

Treatment consisted of continuous inhalation of 60 per cent oxygen at atmospheric pressure and frequent 20 minute periods of 100 per cent oxygen with $5 \mathrm{~cm}$. of water expiratory resistance.

Improvement was rapid. Graded exercises were begun on February 23rd, 6 days after admission. On discharge, March 3rd, 19 days after admission, he was able to perform moderately heavy work without respiratory distress or fatigue.

A roentgenogram of the chest taken on the day of admission exhibited slight clouding in the cardiohepatic angle. On the seventh day, roentgenograms of the lungs and sinuses appeared normal.

COURSE FOLLOWING FIRST ADMISSION TO THE HOSPITAL: The patient returned to work but was able to do only light labor because of pain over the left chest, similar to that which he had experienced for the past 6 years, tenderness to touch over the precordium, and shortness of breath on moderate exertion. These symptoms were still present when he was readmitted to the hospital on May 28,1944 , more than 3 months after the last inhalation of phosgene and again on January 10,1945, approximately 6 months later. The only disturbance noted on physical examination was rapid, shällow abdominal breathing. The chest remained immobile except during deep inspiration when it expanded $7 \mathrm{~cm}$. He was taught breathing exercises to encourage the use of his chest muscles in respiration. His symptoms did not improve during the period of hospitalization. His capacity for work appeared to be limited moderately.
PSychiatric Summary : L. T. is a stable, well-adjusted colored male, who seems to have lived a very satisfactory life with a good work record and a well-rounded program of activities. In a conscientious sort of way, he has maintained wholesome personal contacts with relatives and friends which afforded him a considerable amount of emotional support and security. His reaction to the exposure was not accompanied by any remarkable emotional reaction, and his subsequent personal adjustment has remained good, though he continues to have some symptoms which he finds not too disturbing and to which he is able to adjust quite well, so that he has been able to resume work and live reasonably comfortably. Largely, it would appear, as a result of his previous excellent personality synthesis, he has been able to overcome the difficulties and to maintain a very reasonable attitude, with little tendency toward the development of an invalid reaction.

PULMONARY FUNCTION STUDIES: Vital capacity is abnormally low. The relationship of the residual air to the total lung volume is at the extreme upper limit of the normal range (Figure 4B).

The respiratory rate at rest is rapid, the tidal air, at the lower limit of the normal range, and the minute volume of respiration, abnormally high. Breathing oxygen does not alter the pattern of respiration. During exercise, the minute volume increases through depth of respiration. The rate becomes slower but is still rapid. The rate of oxygen extraction at rest is generally below the limit of normal variation, and the rate of carbon dioxide output

TABLE IVA

Respiratory pattern resting

\begin{tabular}{|c|c|c|c|c|c|c|c|c|}
\hline \multirow{2}{*}{$\begin{array}{l}\text { Date } \\
1944\end{array}$} & \multirow{2}{*}{$\begin{array}{c}\text { Experi- } \\
\text { ment }\end{array}$} & \multirow{2}{*}{$\begin{array}{l}\text { Resp. } \\
\text { rate }\end{array}$} & \multirow{2}{*}{${ }_{\text {air }}^{\text {Tidal }}$} & \multirow{2}{*}{$\begin{array}{c}\text { Min. } \\
\text { vol. }\end{array}$} & \multicolumn{2}{|c|}{ Alveolar air } & \multicolumn{2}{|c|}{ Expired sir } \\
\hline & & & & & $\mathrm{pO}_{2}$ & $\mathrm{pCO}_{2}$ & $\mathrm{O}_{2}$ & $\mathrm{CO}_{2}$ \\
\hline & & & $m l$. & l. & & & $\begin{array}{c}\text { per } \\
\text { cent }\end{array}$ & $\begin{array}{c}\text { per } \\
\text { cent }\end{array}$ \\
\hline $5 / 30$ & Air & 36 & 427 & 15.30 & 110.2 & 41.4 & 19.15 & 1.38 \\
\hline $5 / 31$ & Air & $\begin{array}{l}04 \\
42\end{array}$ & 413 & 15.65 & $\overline{87.9}$ & $\overline{48.0}$ & 二 & 1.86 \\
\hline $6 / 3$ & $\begin{array}{l}\mathrm{O}_{2} \\
\mathrm{Air} \\
\mathrm{O}_{2}\end{array}$ & $\begin{array}{l}30 \\
38 \\
37.5\end{array}$ & $\begin{array}{l}434 \\
422 \\
379\end{array}$ & \begin{tabular}{|l|}
15.55 \\
16.05 \\
13.05
\end{tabular} & $\overline{104.4}$ & $\overline{41.1}$ & 18.56 & $\begin{array}{l}2.21 \\
1.94 \\
1.98\end{array}$ \\
\hline
\end{tabular}

Exercise*

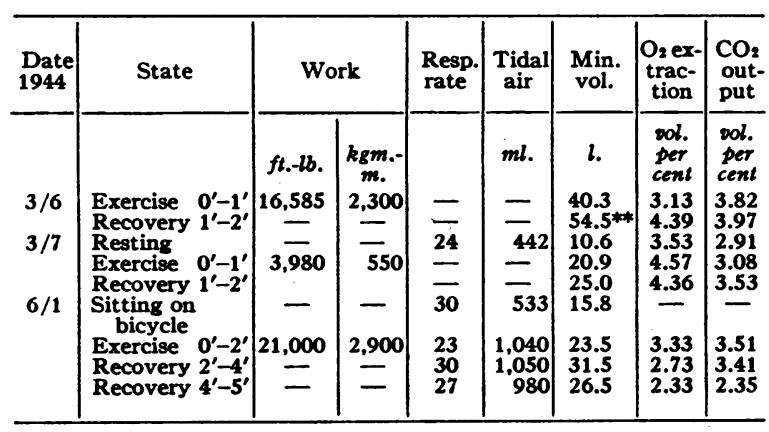

* Bicycle ergometer.

** Subjective dyspnea at this level. 
TABLE IVB Arterial blood studies

\begin{tabular}{|c|c|c|c|c|c|c|c|}
\hline $\begin{array}{l}\text { Date } \\
1944\end{array}$ & State & $\begin{array}{l}\mathrm{CO}_{2} \\
\text { con- } \\
\text { tent }\end{array}$ & $\mathrm{pH}$ & $\mathrm{pCO}_{2}$ & $\begin{array}{c}\mathrm{O}_{2} \\
\text { con- } \\
\text { tent }\end{array}$ & $\underset{\text { capa- }}{\mathrm{O}_{2}}$ & $\begin{array}{l}\text { Satu- } \\
\text { ration }\end{array}$ \\
\hline $\begin{array}{l}3 / 5 \\
6 / 1\end{array}$ & $\begin{array}{l}\text { Room air } \\
\text { Room air }\end{array}$ & $\begin{array}{c}\text { vol. } \\
\text { per } \\
\text { cent } \\
\overline{55.6}\end{array}$ & $\overline{7.37}$ & $\overline{42}$ & $\begin{array}{c}\text { ool. } \\
\text { per } \\
\text { cent } \\
16.0 \\
19.4\end{array}$ & $\begin{array}{c}\text { ool. } \\
\text { per } \\
\text { cent } \\
16.9 \\
20.6\end{array}$ & $\begin{array}{c}\text { per } \\
\text { cent } \\
94.7 \\
94.0\end{array}$ \\
\hline
\end{tabular}

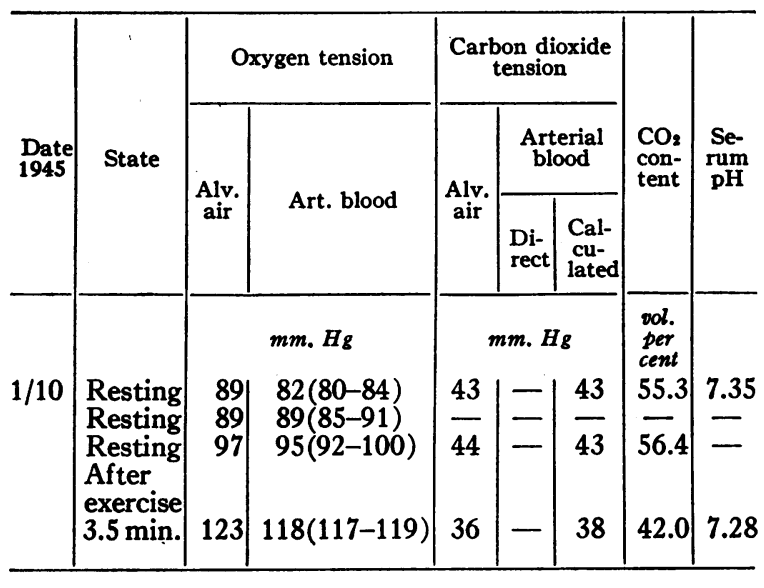

is below or close to the lowest extreme of the normal range (Table IVA).

The dilution rate of nitrogen when oxygen is breathed is slow. Intrapulmonary mixing is impaired and the pulmonary emptying rate is slow (Figures $4 \mathrm{~B}, 4 \mathrm{C}$ ).

The oxygen saturation of arterial blood at rest is normal (Table IVB). The arterial blood and alveolar air oxygen and carbon dioxide tension studies indicate that there is no disturbance in gaseous exchange in the lungs (Table IVB).

The voluntary breathing capacity when erect is 111.6 liters or 99.5 per cent of the predicted value. The breathholding time in room air was 20 seconds in three efforts. The alveolar air carbon dioxide tension was $47 \mathrm{~mm}$. $\mathrm{Hg}$, and the oxygen tension, $65.8 \mathrm{~mm}$. $\mathrm{Hg}$ at the breaking point.

Passive change in posture on a tilt table is accompanied by no unusual respiratory or circulatory response. The cardiac output is 1.37 liters per minute per square meter body surface area. This is a normal value.

sumMary: Pulmonary ventilation is impaired as indicated by a relatively reduced vital capacity and complementary air, and a relatively increased residual air and mid-capacity, impaired intrapulmonary mixing, and slow pulmonary emptying rate. These changes are consistent with pulmonary emphysema.

There is hyperventilation characterized by rapid and relatively shallow breathing. Respiratory function at rest and during exercise is adequate.
Case 5 (S. O., Female, Age 43, Record No. 313427). Height $156 \mathrm{~cm}$., Weight 58.6 kgm., Surface Area $1.57 \mathrm{M}^{2}$.

The patient worked in the phosgene plant, Edgewood Arsenal, for approximately 2 months prior to accidental inhalation of a low concentration of phosgene for about 10 minutes on January 22, 1944.

She was promptly admitted to the Station Hospital, Edgewood Arsenal, where she complained of sneezing, watering of the eyes, substernal distress, and nausea and vomiting.

Her conjunctivae and pharynx were injected. The thorax was symmetrical, expansion shallow and equal. The lungs were clear throughout. The level of arterial pressure was $116 / 70$. There were no signs of heart failure.

COURSE IN STATION HOSPITAL: Injection of the pharynx and conjunctivae cleared in a few days. Pulmonary edema did not develop. She frequently complained of shortness of breath on moderate exertion, cough, weakness, and pain over the heart. She was afebrile.

A teleoroentgenogram was interpreted as exhibiting old obliteration of the right costophrenic sulcus, chronic diffuse emphysema, and a partially calcified nodule in the right upper lobe. The heart appeared normal. When the patient was discharged on February 1, after 16 days of hospitalization, she still had the previously mentioned complaints.

SUBSEQUENT COURSE (Figure 5A): The patient was admitted to the Johns Hopkins Hospital 1 week later because of persistence of symptoms. There was a nonproductive cough, obliteration of cardiac flatness by pulmonary resonance. The lungs were clear throughout.

The cough gradually diminished but her tolerance for exercise remained limited at the time of discharge, after 20 days of hospitalization.

She was readmitted to the hospital on March 21, 1944, for 19 days and again on May 29, 1944, for 11 days because of symptoms which were the same as on the first admission.

On each admission, no abnormalities were found on physical examination. She had numerous minor complaints and there often was slight tenderness to the touch in the 4 th and 5 th interspaces about the mid-clavicular line on the left.

Treatment with 60 per cent oxygen sometimes gave symptomatic relief. Breathing exercises and encouragement seemed the most effective treatment.

When last observed in June, 1944, approximately 6 months after the accident, there was no change in symptoms, tolerance for work and physical findings.

PSYCHIATRIC SUMMARY: S. O. is a somewhat timid, ineffectual, but conscientious person, who has reacted to her exposure by developing considerable anxiety with depressive manifestations. Her past life has been rather unhappy, she is an immature person, and depended on her family for emotional support, though she experienced very little real satisfaction in life. Through her work she hoped to emancipate and find some comfort in her more independent adjustment, but things did not turn out 
as anticipated. The social transplantation, with the severing of old friendships and wholesome interpersonal contacts, did not work out so well. As a result there was a fertile field for the development of neurotic trends which developed following her psychologically traumatic experience and tended to exaggerate the bodily complaints and anxiety-like manifestations commonly seen in these people. Compensation issues, more or less unconsciously motivated, provided an impetus for the development of an invalid reaction with anxiety, hypochondriacal, and reactive depressive trends. Unfortunately, this illness has permitted the patient to develop a martyr-like attitude which serves a useful purpose as far as her personal needs are concerned so that it seems doubtful if she will be able to develop easily any real incentive to get better.

PULMONARY FUNCTION STUDIES: The components of the total lung volume are within the normal range. The data do not allow a calculation of the exact proportions (Table VA).

The rate of breathing is rapid, the depth is variable from test to test, although relatively constant during any one test. The tidal air is generally very low. The minute volume is higher than normal, especially when the tidal is larger than usual, as the patient does not compensate with a slower rate. During exercise, the depth is greatly increased and the minute volume becomes excessive even with mild exercise. Hyperventilation continues for at least 5 minutes after exercise. The expired air at rest contains little carbon dioxide and an abnormally high oxygen concentration, and a similar trend is observed during and following exercise. The alveolar air is of approximately normal composition (Table VB).

On oxygen breathing, the rate of dilution of lung nitrogen is slow, but no disturbance of mixing of gases is demonstrated (Figures 5B, 5C).

The arterial oxygen saturation is abnormally low at rest and rises during exercise and when breathing 100 per cent oxygen (Table VC).

The voluntary breathing capacity measured while standing is abnormally low. It is $\mathbf{5 5 . 5}$ liters or 69.5 per cent of the predicted value. Breath-holding is limited to 23 to 26 seconds and is not influenced by hyperventilation or oxygen breathing.

TABLE VA

Subdivision of lung volume

\begin{tabular}{l|c|c|c}
\hline \hline & $\begin{array}{c}\text { Observed } \\
\text { volume }\end{array}$ & $\begin{array}{c}\text { Predicted } \\
\text { volume }\end{array}$ & $\begin{array}{c}\text { Observed } \\
\text { Predicted }\end{array}$ \\
\cline { 2 - 3 } $\begin{array}{c}\text { Vital capacity } \\
\text { (erect) }\end{array}$ & 3,475 & 3,020 & 115.0 \\
$\begin{array}{c}\text { Complementary } \\
\text { air (erect) }\end{array}$ & 2,550 & 1,985 & 128.5 \\
$\begin{array}{c}\text { Reserve air } \\
\text { (erect) } \\
\text { Mid-capacity } \\
\text { (recumbent) }\end{array}$ & 1,055 & 1,035 & 102.0 \\
\hline
\end{tabular}

TABLE VB

Respiratory pattern resting

\begin{tabular}{|c|c|c|c|c|c|c|c|c|}
\hline \multirow{2}{*}{$\begin{array}{l}\text { Date } \\
1944\end{array}$} & \multirow{2}{*}{$\begin{array}{c}\text { Experi- } \\
\text { ment }\end{array}$} & \multirow{2}{*}{$\begin{array}{l}\text { Resp. } \\
\text { rate }\end{array}$} & \multirow{2}{*}{$\begin{array}{c}\text { Tidal } \\
\text { air }\end{array}$} & \multirow{2}{*}{$\begin{array}{l}\text { Min. } \\
\text { vol. }\end{array}$} & \multicolumn{2}{|c|}{ Alveolar air } & \multicolumn{2}{|c|}{ Expired air } \\
\hline & & & & & $\mathrm{pO}_{2}$ & $\mathrm{pCO}_{2}$ & $\mathrm{O}_{2}$ & $\mathrm{CO}_{2}$ \\
\hline & & & $m l$. & $l$. & & & $\begin{array}{l}\text { per } \\
\text { cent }\end{array}$ & $\begin{array}{l}\text { per } \\
\text { cent }\end{array}$ \\
\hline $\begin{array}{l}4 / 12 \\
4 / 15 \\
4 / 24 \\
6 / 5\end{array}$ & $\begin{array}{l}\mathrm{O}_{2} \\
\mathrm{O}_{2} \\
\mathrm{O}_{2} \\
\text { Air }\end{array}$ & $\begin{array}{l}21.5 \\
17.0 \\
34.5 \\
23.5\end{array}$ & $\begin{array}{l}265 \\
413 \\
225 \\
385\end{array}$ & $\begin{array}{l}6.64 \\
6.94 \\
7.82 \\
9.05\end{array}$ & $\begin{array}{l}\overline{-} \\
652.0 \\
107.2\end{array}$ & $\overline{\bar{F}}$ & $\overline{\overline{1}}$ & $\begin{array}{l}2.01 \\
2.62 \\
1.52 \\
2.25\end{array}$ \\
\hline & $\mathrm{O}_{2}$ & 27.5 & $\begin{array}{l}412 \\
387\end{array}$ & $\begin{array}{r}10.08 \\
8.60\end{array}$ & 661.0 & 33.9 & $=$ & 3.54 \\
\hline $0 / 0$ & $U_{2}$ & 22.0 & 381 & 8.60 & 660.0 & 40.2 & - & 2.26 \\
\hline
\end{tabular}

Exercise *

\begin{tabular}{|c|c|c|c|c|c|c|c|c|}
\hline \multirow[t]{2}{*}{$\begin{array}{l}\text { Date } \\
1944\end{array}$} & \multirow[t]{2}{*}{ State } & \multicolumn{2}{|c|}{ Work } & \multirow[t]{2}{*}{$\begin{array}{l}\text { Resp. } \\
\text { rate }\end{array}$} & \multirow{2}{*}{$\begin{array}{c}\begin{array}{c}\text { Tida } \\
\text { air }\end{array} \\
\text { ml. }\end{array}$} & \multirow{2}{*}{$\begin{array}{c}\begin{array}{c}\text { Min. } \\
\text { vol. }\end{array} \\
l .\end{array}$} & \multirow{2}{*}{ 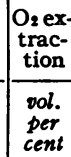 } & \multirow{2}{*}{$\begin{array}{c}\mathrm{CO} \\
\text { out- } \\
\text { put }\end{array}$} \\
\hline & & $f t .-l b$ & $\underset{\mathrm{mg} .-}{\mathrm{kgm} .}$ & & & & & \\
\hline \multirow{5}{*}{$\begin{array}{l}2 / 25 \\
2 / 26\end{array}$} & Resting & .5 & $a^{-1}$ & - & - & 5.30 & - & - \\
\hline & Exercise $0^{\prime}-1^{\prime}$ & 1,640 & 227 & - & 二 & $\begin{array}{l}22.60 \\
25.00\end{array}$ & 4.18 & 3.63 \\
\hline & Recovery $2^{\prime}-3^{\prime}$ & 二 & - & 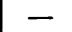 & 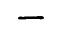 & 16.30 & & \\
\hline & Recovery $3^{\prime}-4^{\prime}$ & 一 & - & - & - & 13.35 & 2.79 & 2.80 \\
\hline & $\begin{array}{l}\text { Recovery } 4^{\prime}-5^{\prime} \\
\text { Recovery } 5^{\prime}-6^{\prime}\end{array}$ & - & 二 & 二 & 二 & \begin{tabular}{|l|}
13.60 \\
12.05
\end{tabular} & $\overrightarrow{2.06}$ & $2 \overline{03}$ \\
\hline \multirow[t]{2}{*}{$4 / 26$} & Resting (on & - & - & 34 & 210 & 7.20 & - & - \\
\hline & Exercise $0^{\prime}-1^{\prime}$ & $200 * *$ & 一 & 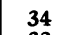 & 1,020 & 34.70 & - & - \\
\hline \multirow[t]{3}{*}{$4 / 26$} & $\begin{array}{l}\text { Recovery 1'-2' } \\
\text { Resting (on }\end{array}$ & 一 & 二 & $\begin{array}{l}32 \\
36\end{array}$ & $\begin{array}{l}835 \\
260\end{array}$ & $\begin{array}{r}26.80 \\
9.30\end{array}$ & 二 & 二 \\
\hline & $\begin{array}{l}\text { Exercise) } \\
\text { Exer-1 }\end{array}$ & $220 *+$ & - & 35 & 1,240 & 43.30 & - & 一 \\
\hline & Recovery $1^{\prime}-2^{\prime}$ & & & 40 & 812 & 32.50 & & \\
\hline
\end{tabular}

* Bicycle ergometer.

** Work was obviously greater than measured.

TABLE VC

Arterial blood studies

\begin{tabular}{|c|c|c|c|c|}
\hline Date 1944 & State & $\mathrm{O}_{2}$ content & $\mathrm{O}_{2}$ capacity & Saturation \\
\hline $\begin{array}{l}2 / 14 \\
4 / 27\end{array}$ & $\begin{array}{l}\text { Room air } \\
\text { Oxygen } \\
\text { Room air } \\
\text { Room air- } \\
\quad \text { exercise }\end{array}$ & $\begin{array}{c}\text { vol. per cent } \\
13.7 \\
14.4 \\
14.3 \\
15.7\end{array}$ & $\begin{array}{c}\text { ool. per cent } \\
15.0 \\
14.6 \\
16.0 \\
16.4\end{array}$ & $\begin{array}{c}\text { per cent } \\
91.3 \\
98.6 \\
92.4 \\
95.6\end{array}$ \\
\hline
\end{tabular}

Passive change in posture on a tilt table is not accompanied by any abnormal circulatory response. There is a moderate increase in the rate of respiration in the horizontal position and mild hyperventilation occurs after tilting in either direction.

SUMMARY: The relationship among the components of the total lung volume is normal. The abnormally low arterial blood oxygen saturation, in the absence of impaired intrapulmonary mixing of gases, indicates that the disturbed respiratory function is not related primarily to the rapid, shallow breathing.

Case 6 (M. P., Female, Age 49, Record No. 317296). Height $159 \mathrm{~cm}$., Weight $56 \mathrm{kgm}$., Surface Area $1.55 \mathrm{M}^{2}$.

The patient worked in the chlorine plant, Edgewood Arsenal, during the summer of 1941. On July 15, 1941, 
she accidentally inhaled several breaths of chlorine. She soon felt faint, short of breath on moderate exertion, became nauseated, vomited, and her throat felt sore. When she continued to feel "sick" the next day she was admitted to the Station Hospital, Edgewood Arsenal. She was discharged after a few hours. The symptoms persisted for the next 3 months.

She worked in the phosgene plant from January, 1942 to January 22, 1944.

During two weeks in December, 1943, she had several short exposures to phosgene which caused her to cough and vomit.

The patient was admitted to the Station Hospital, Edgewood Arsenal, on January 22, 1944, 11/2 hours after she accidentally inhaled several breaths of phosgene which had escaped from leaking shells.

The patient was coughing violently, was nauseated, vomited, and had a nasal and lachrymal discharge.

She appeared ill. Respirations were 24 a minute, shallow. There was no cyanosis, orthopnea or dyspnea. The lungs were clear throughout; the pulse 96 per minute, regular. The level of arterial pressure was 120/80.

When discharged from the hospital after 5 days, January 26 , she complained of soreness over the left side of the anterior aspect of the chest, slight shortness of breath on moderate exertion, and a non-productive cough. The lungs were clear and there was no limitation of excursion of the chest.

Roentgenograms of the lungs on admission and on the following day appeared normal. There was no leukocytosis, there was a moderate degree of normocytic anemia.

SUBSEQUENT COURSE: The patient has been unable to work steadily even at light clerical work because of precordial pain not necessarily related to effort, shortness of breath on moderate exertion, cough, and nausea and vomiting after meals.

She was observed in the hospital for $61 / 2$ weeks in March and April, 1944 and in January, 1945 for 2 days.

There have been no new physical findings. Roentgenograms of the gastrointestinal tract were normal. Electrocardiograms were normal. The anemia improved. Urine examinations were normal.

Treatment consisted of frequent massage to the legs and deep breathing exercises.

PSYCHIATRIC SUMMARY: M. P. is a modestly endowed individual with a simple social background, few outside interests, and limited interpersonal contacts upon which she can lean for emotional support. She is a conscientious, well-meaning person, with a good work record from which she obtains some additional satisfaction by being able to contribute to the national effort during the wartime emergency. Though she has the usual multiple somatic complaints and anxiety-like manifestations seen in these patients, she seems earnestly interested in trying to overcome her difficulties and in making a better personal adjustment. Emotionally she displays some instability with mild.depressive trends, and some tearfulness. Clinically, the description might be that of a reactive depression with hypochondriacal and anxiety features found in a modestly endowed, conscientious woman, who probably has some more or less definite physiological bases for her symptoms which are, however, exaggerated by emotional factors; she has a strong tendency to flirt with a chronic invalid reaction with its potential gains. This attitude has been fostered to a certain extent by the numerous repeated examinations that had to be done for research reasons, and was enhanced in a way by the contacts with other patients who under similar circumstances seemed sicker, more incapacitated, and consequently standing a better chance for compensation, though it is doubtful if the patient was consciously aware of this aspect of her illness.

PULMONARY FUNCTION STUDIES: The vital capacity and the mid-capacity of the lungs are within the normal range (Table VIA).

The tidal air at rest is usually shallow, the respiratory rate is variable, and the minute volume, moderately high. The alveolar air carbon dioxide tension is generally slightly increased. During moderate exercise, the breathing becomes very rapid with only slight increase in tidal air (Table VIB).

TABLE VIA

Subdivisions of lung volume

\begin{tabular}{|c|c|c|c|}
\hline & $\begin{array}{c}\text { Ob- } \\
\text { served } \\
\text { volume }\end{array}$ & $\begin{array}{c}\text { Pre- } \\
\text { dicted } \\
\text { volume }\end{array}$ & $\frac{\text { Observed }}{\text { Predicted }} \times 100$ \\
\hline $\begin{array}{l}\text { Vital capacity (erect) } \\
\text { Mid-capacity (recumbent) }\end{array}$ & $\begin{array}{c}m l . \\
3,200 \\
2,000\end{array}$ & $\begin{array}{c}m l . \\
3,130 \\
1,750\end{array}$ & $\begin{array}{l}102.0 \\
114.0\end{array}$ \\
\hline
\end{tabular}

TABLE VIB

Respiratory pattern

\begin{tabular}{c|c|c|c|c|c|c|c|c}
\hline \hline $\begin{array}{c}\text { Date } \\
1944\end{array}$ & $\begin{array}{c}\text { Experi- } \\
\text { ment }\end{array}$ & $\begin{array}{c}\text { Resp. } \\
\text { rate }\end{array}$ & $\begin{array}{c}\text { Tidal } \\
\text { air }\end{array}$ & $\begin{array}{c}\text { Min. } \\
\text { vol. }\end{array}$ & \multicolumn{2}{|c|}{ Alveolar air } & \multicolumn{2}{|c|}{ Expired air } \\
\cline { 5 - 8 } & & & & $\mathrm{pO}_{2}$ & $\mathrm{pCO}_{2}$ & $\mathrm{O}_{2}$ & $\mathrm{CO}_{2}$ \\
\hline & & & $\mathrm{ml}$. & $l$. & & & $\begin{array}{c}\text { per } \\
\text { cent }\end{array}$ & $\begin{array}{c}\text { per } \\
\text { cent }\end{array}$ \\
$4 / 12$ & $\mathrm{O}_{2}$ & 24.0 & 295 & 7.07 & 556.0 & 37.1 & - & 2.01 \\
$4 / 14$ & $\mathrm{O}_{2}$ & 17.0 & 320 & 5.41 & 626.0 & 47.2 & - & 3.66 \\
$4 / 17$ & $\mathrm{O}_{2}$ & 18.0 & 282 & 5.11 & 581.0 & 41.7 & - & 2.66 \\
$4 / 21$ & $\mathrm{O}_{2}$ & 12.5 & 375 & 4.70 & 622.0 & 47.6 & - & 3.89 \\
Air & 11.0 & 407 & 4.45 & 95.5 & 47.6 & - & 4.25 \\
\hline
\end{tabular}

Exercise *

\begin{tabular}{|c|c|c|c|c|c|c|}
\hline $\begin{array}{l}\text { Date } \\
1944\end{array}$ & State & & ork & $\begin{array}{l}\text { Resp. } \\
\text { rate }\end{array}$ & $\underset{\text { air }}{\text { Tidal }}$ & $\begin{array}{l}\text { Min. } \\
\text { vol. }\end{array}$ \\
\hline $5 / 6$ & $\begin{array}{l}\text { Resting } \\
\text { Exercise } 0^{\prime}-1^{\prime} \\
\text { Recovery } 1^{\prime}-2^{\prime} \\
\text { Recovery } 2^{\prime}-3^{\prime} \\
\text { Exercise } 0^{\prime}-1^{\prime} \\
\text { Recovery } 1^{\prime}-2^{\prime} \\
\text { Recovery } 2^{\prime}-3^{\prime}\end{array}$ & $\begin{array}{c}f t .-l b . \\
\overline{2,000} \\
- \\
\overline{4} \\
\overline{-420} \\
-\end{array}$ & $\begin{array}{c}\mathrm{kgm}_{\mathbf{-}-m} . \\
\overline{277} \\
- \\
\overline{612} \\
-\end{array}$ & $\begin{array}{l}20 \\
45 \\
50 \\
41 \\
60 \\
50 \\
42\end{array}$ & $\begin{array}{l}m l . \\
300 \\
465 \\
312 \\
300 \\
340 \\
432 \\
370\end{array}$ & $\begin{array}{c}l . \\
6.0 \\
20.9^{* *} \\
15.6 \\
12.2^{*} \\
19.2^{* *} \\
21.6^{* *} \\
15.4\end{array}$ \\
\hline
\end{tabular}

* Bicycle ergometer. ** Dyspnea. 
TABLE VIC

Arterial blood studies

\begin{tabular}{c|c|c|c|c}
\hline \hline Date 1944 & State & $O_{2}$ content & $O_{2}$ capacity & Saturation \\
\cline { 2 - 4 } $5 / 3$ & Resting & $\begin{array}{c}\text { vol. per cent } \\
16.7\end{array}$ & $\begin{array}{c}\text { vol. per cent } \\
16.7\end{array}$ & $\begin{array}{c}\text { per cent } \\
100.0\end{array}$ \\
\hline
\end{tabular}

\begin{tabular}{|c|c|c|c|c|c|c|c|c|}
\hline \multirow{3}{*}{$\begin{array}{l}\text { Date } \\
1945\end{array}$} & \multirow{3}{*}{ State } & \multicolumn{2}{|c|}{ Oxygen tension } & \multicolumn{3}{|c|}{$\begin{array}{c}\text { Carbon dioxide } \\
\text { tension }\end{array}$} & \multirow{3}{*}{$\begin{array}{l}\mathrm{CO} 2 \\
\text { con- } \\
\text { tent }\end{array}$} & \multirow{3}{*}{$\begin{array}{l}\text { Se- } \\
\text { rum } \\
\text { pH }\end{array}$} \\
\hline & & \multirow{2}{*}{$\begin{array}{l}\text { Alv. } \\
\text { air }\end{array}$} & \multirow{2}{*}{ Art. blood } & \multirow{2}{*}{$\begin{array}{l}\text { Alv. } \\
\text { air }\end{array}$} & \multicolumn{2}{|c|}{$\begin{array}{c}\text { Arterial } \\
\text { blood }\end{array}$} & & \\
\hline & & & & & $\begin{array}{l}\text { Di- } \\
\text { rect }\end{array}$ & $\begin{array}{l}\text { Cal- } \\
\text { cu- } \\
\text { lated }\end{array}$ & & \\
\hline & & & $m m . H_{g}$ & & $m . H$ & & $\begin{array}{l}\text { vol. } \\
\text { per } \\
\text { cent }\end{array}$ & \\
\hline $1 / 9$ & $\begin{array}{l}\text { Resting } \\
\text { Resting } \\
\text { Deep breathing }\end{array}$ & $\begin{array}{r}103 \\
95 \\
101\end{array}$ & $\begin{array}{l}104 \\
96(92-99) \\
99(94-104)\end{array}$ & $\frac{45}{40}$ & $\frac{44}{-}$ & $\frac{47}{45}$ & $\frac{60.0}{58.0}$ & $\frac{7.35}{7.36}$ \\
\hline
\end{tabular}

During oxygen breathing, the rate of dilution of alveolar nitrogen is slow. With shallow breathing, the observed nitrogen exceeds the predicted concentration especially at about 100 breaths. When the patient's breathing is slow and deep ( 5 per cent carbon dioxide added and voluntary control), the observed nitrogen concentration agrees closely with the predicted value. Apparently there are portions of the lungs which are poorly ventilated during shallow breathing but which react quite normally when depth is increased (Figures 6A, 6B).

The oxygen saturation of arterial blood at rest is normal. The arterial blood and alveolar air oxygen tension studies indicate that there is no disturbance in exchange of these gases in the lungs (Table VIC).

The voluntary breathing capacity in the erect posture is normal. It is 68.8 liters or 92.3 per cent of the expected value. Breath-holding time is normal.

The response to passive change in posture is normal. The cardiac output is 1.36 liters per minute per square meter body surface area. This is a normal value.

SUMMARY: The outstanding feature in this patient is the shallow breathing accompanied by moderately impaired intrapulmonary mixing of gases. This does not lead to anoxemia. Intrapulmonary mixing of gases is not impaired when respirations are deepened. Respiratory function of the lungs is not impaired.

\section{BIBLIOGRAPHY}

1. The symptoms and treatment of the late effects of gas poisoning, No. 3, Reports of the Chemical Warfare Medical Committee, British. April, 1918.

2. Barcroft, J., Hunt, G. H., and Dufton, D., Polycythemia after gas poisoning and the effect of oxygen administration in chambers in the treatment of chronic cases, No. 4, Reports of the Chemical Warfare Medical Committee, British. April, 1918.
3. Haldane, J. S., Meakins, J. C., and Priestley, J. G., The reflex restriction of respiration after gas poisoning, No. 5, Reports of the Chemical Warfare Medical Committee, British. April, 1918.

4. Hunt, G. H., Peters, R. A., Meakins, J. C., and Walker, T. W., Changes observed in the heart and circulation and the general after-effects of irritant gas poisoning, No. 7, Reports of the Chemical Warware Medical Committee, British. April, 1918.

5. Haldane, J. S., Meakins, J. C., and Priestley, J. G., Investigations of chronic cases of gas poisoning, No. 11, Reports of the Chemical Warfare Medical Committee, British. October, 1918.

6. Barcroft, J., Hunt, G. H., and Dufton, D., Treatment of patients suffering from effort syndrome by continuous inhalation of oxygen, No. 12, Reports of the Chemical Warfare Medical Committee, British. October, 1918.

7. Hunt, G. H., and Jones, C. P., A note on the later effects of poisoning by asphyxiating gas, No. 15, Reports of the Chemical Warfare Medical Committee, British. November, 1918.

8. Meakins, J. C., and Priestley, J. G., Report on the length of stay in hospital in the United Kingdom and the disposal of gas casualties, No. 16, Reports of the Chemical Warfare Medical Committee, British. November, 1918.

9. History of the great war based on official documents. Great Britain, 1923, 2, 520.

10. Blackmore, S., Discussion on the effects of asphyxiating gases on the respiratory system. Proc. Royal Soc. Med., 1937, 30, 1033.

11. Professor Achard and Major Flandin, quoted in: History of the great war based on official documents. Great Britain, 1923, 2, 407.

12. Berghoff, R. S., The more common gases, their effect on the respiratory tract; observations on 2,000 cases. Arch. Int. Med., 1919, 24, 678.

13. Pearce, R. G., Note on some respiratory studies made on late stages of gas poisoning. J. Lab. and Clin. Med., 1920, 5, 411.

14. Haggard, H. W., Action of irritant gases upon the respiratory tract. J. Ind. Hygiene, 1924, 5, 390.

15. Sergent, E., The respiratory sequelae of poisoning by war gases. Presse Medicale, 1925, 33, 201.

16. Gilchrist, H. L., and Matz, P. B., The residual effects of warfare gases. I. Chlorine. II. Mustard. War Dept., U. S. Government Printing Office, Washington, 1933.

17. Gilchrist, H. L., and Matz, P. B., The residual effects of warfare gases: the use of phosgene gas, with report of cases. The Medical Bulletin of the Veterans' Administration, 1933, 10, 1.

18. Maire, G., Hugonot, G., Giradin, M., and Thoral, L., Lesions of respiratory tract due to war gases. Revue du Service de Sante Militarie, 1938, 109, 745.

19. Darling, R. C., Cournand, A., and Richards, D. W., Jr., Studies on the intrapulmonary mixture of 
gases. III. An open circuit method for measuring residual air. J. Clin. Invest., 1940, 19, 609.

20. Cournand, A., Baldwin, E. DeF., Darling, R. C., and Richards, D. W., Jr., Studies on intrapulmonary mixture of gases. IV. The significance of the pulmonary emptying rate and a simplified open circuit measurement of residual air. J. Clin. Invest., 1941, 20, 681.

21. Kaltreider, N. L., Fray, W. W., and Hyde, H. Van $Z$., The effect of age on the total pulmonary capacity and its subdivisions. Amer. Rev. Tuberc., 1938, 37, 662.

22. Robinson, S., Experimental studies of physical fitness in relation to age. Arbeitsphysiol., 1938, 10, 251.

23. Bohr, C., Ueber die lungenathmung. Skand. Arch. f. Physiol., 1891, 2, 236.

24. Darling, R. C., Cournand, A., and Richards, D. W., Jr., Studies on intrapulmonary mixture of gases. V. Forms of inadequate ventilation in normal and emphysematous lungs, analyzed by means of breathing pure oxygen. J. Clin. Invest., 1944, 23, 55.

25. Cournand, A., and Richards, D. W., Jr., Pulmonary insufficiency. I. Discussion of a physiological classification and presentation of clinical tests. Amer. Rev. Tuberc., 1941, 44, 26.

26. Peters, J. P., and Van Slyke, D. D., Quantitative Clinical Chemistry, Vol. II, Methods, Chapter VII : Gasometric methods for analysis of blood and other solutions. The Williams and Wilkins Co., Baltimore, Md., 1932.

27. Riley, R. L., Proemmel, D. D., and Franke, R. E., A direct method for determination of oxygen and carbon dioxide tensions in blood. J. Biol. Chem., 1945, 161, 621.

28. Comroe, J. H., Jr., and Dripps, R. D., The oxygen tension of arterial blood and alveolar air in normal human subjects. Amer. J. Physiol., 1944, 142, 700.

29. Riley, R. L., A direct method for the determination of carbon dioxide and oxygen tensions in blood. Fed. Proc., 1945, 4, 59.
30. Galdston, M., and Luetscher, J. A., Jr., Oxygen and carbon dioxide tensions in arterial blood and alveolar air at rest and after exercise in healthy subjects and in patients exposed to phosgene. Fed. Proc., 1946, 5, 265.

31. Peters, J. P., Studies of the carbon dioxide absorption curve of human blood. III. A further discussion of the form of the absorption curve plotted logarithmically with a convenient type of interpolation chart. J. Biol. Chem., 1923, 56, 745.

32. Cournand, A., Ranges, H. A., and Riley, R. L., Comparison of results of the normal ballistocardiogram and a direct Fick method in measuring the cardiac output in man. J. Clin. Invest., 1942, 21, 287.

33. Starr, I., and Schroeder, H. A., Ballistocardiogram. II. Normal standards, abnormalities commonly found in diseases of the heart and circulation, and their significance. J. Clin. Invest., 1940, 19, 437.

34. Galdston, M., Luetscher, J. A., Jr., Longcope, W. T., and Bullich, N. L., A study of the residual effects of phosgene poisoning in human subjects. II. After chronic exposure. J. Clin. Invest., 1947, 26, 169.

35. Christie, R. V., Some types of respiration in the neuroses. Quart. J. Med., 1935, 4, 427.

36. Caughey, J. L., Jr., Cardiovascular neurosis-a review. Psychosom. Med., 1939, 1, 311.

37. Cournand, A., Richards, D. W., Jr., and Darling, R. C., Graphic tracings of respiration in study of pulmonary disease. Amer. Rev. Tuberc., 1939, 40, 487.

38. Haldane, J. S., Meakins, J. C., and Priestley, J. G., The effects of shallow breathing. J. Physiol., 1919, 52, 433.

39. Starr, I., Ballistocardiographic studies of draftees rejected for neurocirculatory asthenia. War Med., 1944, 5, 155. 